\title{
CAMA
}

Centre for Applied Macroeconomic Analysis

\section{What happens when the Kiwi flies? The sectoral effects of the exchange rate shocks}

\section{CAMA Working Paper 73/2013 November 2013}

\section{Özer Karagedikli}

Reserve Bank of New Zealand

\section{Michael Ryan}

New Zealand Treasury

\section{Daan Steenkamp}

Reserve Bank of New Zealand

\section{Tugrul Vehbi}

New Zealand Treasury and

The Centre for Applied Macroeconomics Analysis

\section{Abstract}

We estimate a Factor Augmented Vector autoregression (FAVAR) to identify idiosyncratic exchange rate shocks and examine the effects of these shocks on different sectors of the economy. We find that an unexpected shock to the exchange rate has significant effects on the tradable sector of the economy. While this is expected, the nontradable sectors of the economy are also influenced by shocks to exchange rate. We argue that one important channel for this influence is the endogenous/cyclical nature of the population dynamics due to permanent and long term migration. 


\section{Keywords}

\section{JEL Classification}

$\mathrm{C} 22, \mathrm{C} 32, \mathrm{E} 21$

\section{Address for correspondence:}

(E) cama.admin@anu.edu.au

The Centre for Applied Macroeconomic Analysis in the Crawford School of Public Policy has been established to build strong links between professional macroeconomists. It provides a forum for quality macroeconomic research and discussion of policy issues between academia, government and the private sector.

The Crawford School of Public Policy is the Australian National University's public policy school, serving and influencing Australia, Asia and the Pacific through advanced policy research, graduate and executive education, and policy impact. 


\title{
What happens when the Kiwi flies? The sectoral effects of the exchange rate shocks*
}

\author{
Özer Karagedikli ${ }^{1}$, Michael Ryan ${ }^{2}$, Daan Steenkamp ${ }^{1}$, and Tugrul Vehbi ${ }^{3}$ \\ ${ }^{1}$ Reserve Bank of New Zealand \\ ${ }^{2}$ New Zealand Treasury \\ ${ }^{3}$ New Zealand Treasury and CAMA
}

November 13, 2013

\begin{abstract}
We estimate a Factor Augmented Vector autoregression (FAVAR) to identify idiosyncratic exchange rate shocks and examine the effects of these shocks on different sectors of the economy. We find that an unexpected shock to the exchange rate has significant effects on the tradable sector of the economy. While this is expected, the non-tradable sectors of the economy are also influenced by shocks to exchange rate. We argue that one important channel for this influence is the endogenous/cyclical nature of the population dynamics due to permanent and long term migration.
\end{abstract}

JEL-Codes: C22, C32, E21

${ }^{*}$ The views expressed here are the views of the authors and do not necessarily reflect the views of our employers, the Reserve Bank of New Zealand or the New Zealand Treasury. We thank Chris Ball, Peter Mawson, Jacques Poot, Kam Szeto, Gael Price, Yu-chin Chen, and the seminar participants at the Reserve Bank of New Zealand and the New Zealand Association of Economists Conference in Wellington. Özer Karagedikli (corresponding author), Reserve Bank of New Zealand, PO Box 600, Wellington, New Zealand. ozer. karagedikli@rbnz.govt.nz 


\section{Introduction}

This paper is interested in answering the following questions: What happens to different sectors in the economy when the exchange rate appreciates or depreciates unexpectedly? Do some sectors respond more than the others? Are tradable and non-tradable sectors independent of each other in the face of such exchange rate changes? All these are important questions for a small open economy such as New Zealand.

Although there has been a large body of empirical literature on the identification and the effects of monetary policy shocks, there has been much less focus on the effects of exchange rate shocks. One reason for this is the exchange rate is typically believed to be a shock absorber - that is, it responds to other shocks. For example the exchange rate may fall in response to a decline in economic activity in the domestic economy or to a fall in commodity prices. However, others have argued that the exchange rate can also be an independent source of shock (Farrant and Peersman (2006), Mumtaz and Sunder-Plassmann (2010), Buiter (2000)). One could argue, for example, there may be an exogenous change in demand for the currency, unrelated to the economic cycle, such as those reflecting carry trades and/or portfolio reallocation decisions. Artis and Ehrmann (2006) find evidence for the "source of shock" view in the case of Sweden and Denmark, for example.

If indeed the exchange rate is a source of shock then the effects of such exchange rate shocks on the economy is an important question in an open economy such as New Zealand. Several papers have used the Structural VAR (SVAR) approach to identify the effects of exchange rate shocks on the New Zealand economy. Buckle et al. (2007) find that New Zealand dollar exchange rate shocks do not contribute significantly to deviations in GDP from trend. Whilst, Haug and Smith (2007) show that positive real exchange rate shocks (and associated monetary policy responses) result in a fall in domestic output and inflation. However these studies do not look at how the effects of these exchange rate shocks may differ across the different production sectors of the economy.

In the international context, Hahn (2007) investigates how exchange rate shocks affect sectoral activity and prices in the euro zone. Hahn (2007) uses 5 variable SVARs, identified using Cholesky decompositions, ordering the variables in the following order: exchange rate, aggregate GDP, CPI, sector GDP, short term interest rate. The problem with this approach, however, is that the exchange rate shocks used to assess the impact on each sector will be obtained from different models, implying that exchange rate shocks might well be of different sizes and signs in different models. Further, as is typical in VAR studies, Hahn (2007) uses a small number of variables meaning exchange rate movements are typically not well explained, implying that exchange rate shocks will tend to be larger in magnitude.

To address the above concerns this paper estimates a factor augmented vector autoregression (FAVAR) model for the New Zealand economy to identify common 'unanticipated' exchange rate shocks and to assess the transmission of these common shocks to the different sectors in the economy. The FAVAR approach is suited to examining the exchange rate, as it allows the exchange rate to respond to a large number of New Zealand and international variables (over 300 in our case) rather than, say, four or five as in a traditional VAR model such as those estimated by Hahn (2007).

We have two main findings in our study: First, exchange rate shocks have a significant and negative impact on the tradable sectors of the economy. We find that the manufacturing 
sector is the most adversely affected by exchange rate shocks, which the agricultural sector is not affected to a large extent by such shocks. The latter is consistent with earlier research by Buckle et al. (2007) showing that developments in New Zealand's pastoral sector tend to be driven by climatic shocks over the short term. Second, an exchange rate shock also has significant effects on the non-tradable sector. We provide a possible explanation that focuses on the relationship between New Zealand's relative business cycle, migration dynamics, housing and the broader economy. The finding that the exchange rate may affect the non-tradable sector suggests that the assumption common in some models (see Swan (1955) and Salter (1959)) that the exchange rate does not affect the non-tradable sector may be overly simplistic.

The remainder of the paper is structured as follows: Section 2 introduces the empirical framework, and discusses estimation and identification, section 3 presents and discusses the results, and section 4 concludes.

\section{Empirical Framework: Model, Estimation and Identifica- tion}

The VAR approach to measuring the effects of different shocks has produced a lot of useful information on the structural questions researchers and policymakers have in mind. But one of the major criticisms of the VAR approach to identification of shocks is the low dimensionality of the information sets used in VARs. Most small open economy VARs are based only on around a handful of variables. However, central banks consider a much larger information set (in the case of identification of monetary policy shocks) when setting policy rates. Exchange rates are similar: market participants look at large number of variables from both domestic and foreign economies as well as more global variables, such as risk measures, uncertainty and commodity prices.

A related criticism of the use of such limited information VARs, is that researchers and policymakers can only observe the effects of the shocks on the same limited number of variables. Instead, researchers and policymakers may want to see the effects of the shocks on a number of different variables. We use a factor augmented vectorautoregression (FAVAR) approach to analyse the effects of exchange rate shocks. The FAVAR approach combines the traditional SVAR approach with estimated unobserved factors stemming from the more recent dynamic factor literature. The recent dynamic factor model literature argues that a large number of series can be summarised by a small number of factors, which helps overcome the criticism discussed above. The factor approach helps in reduction of dimensionality with large data sets.

Our FAVAR uses the general setup of Bernanke et al. (2005). Since the factors we estimate are unobserved and have to be inferred from the data, the model can naturally be represented in a state space form in the following way:

$$
\left[\begin{array}{c}
F_{t} \\
Y_{t}
\end{array}\right]=\beta(L)\left[\begin{array}{c}
F_{t-1} \\
Y_{t-1}
\end{array}\right]+u_{t}
$$

where $F_{t}$ is a set of unobserved factors, and $Y_{t}$ s are observed variables, the domestic interest rate and the exchange rate in our case. $\beta(L)$ is a conformable lag polynomial of order $p$ and $u_{t}$ is the reduced form residuals. The relation between the reduced form and structural disturbances follow $u_{t}=\Omega^{1 / 2} \varepsilon_{t}$, with $\varepsilon \sim N(0,1)$ and $\Omega=\left(A_{0}^{-1}\right)\left(A_{0}^{-1}\right)^{\prime}$. The observation 
equation of the system is:

$$
X_{t}=\Lambda^{F} F_{t}+\Lambda^{Y} Y_{t}+e_{t},
$$

where $X_{t}$ is a $\mathrm{N}$ x 1 vector of observables other than the exchange rate and interest rate, $\Lambda^{F}$ and $\Lambda^{Y}$ are $\mathrm{N} \times \mathrm{K}$ and $\mathrm{N} \times 1$ matrixes of factor loadings. ${ }^{1}$ Finally $e_{t}$ is a $\mathrm{N} \times 1$ vector of idiosyncratic, zero mean, disturbances.

The large dataset, $X_{t}$, contains both domestic and international variables that are of importance in the determination of exchange rates. Like monetary policy settings, the exchange rate responds to all the different data announcements that come out in a given quarter in New Zealand and also from the rest of the world. We argue that the common factors we estimate will capture relative differences in these domestic and the foreign variables.

For the identification of the shocks in the VAR, we use a Cholesky identification scheme and order the factors and the interest rate above the exchange rate. The ordering of interest rates before the exchange rates assumes that the exchange rate responds to the current quarter movements in interest rate but not vice versa.

To identify exchange rate (and also the interest rate shocks), and justify the ordering of the variables described above, we need to ensure that the factors extracted from the $X$ matrix do not include any variable that in theory will react contemporaneously with the exchange rate. For example, the yield curve variables, domestic currency tradable inflation variables and some expectation variables might be responding to the current quarter movements in the exchange rate. This would violate the ordering assumption in the VAR. To address this, we rotate the fast moving variables against both the interest rate and the exchange rate. The rotation essentially takes the contemporaneous effects of the exchange rate and interest rate out of the factors. Once the factors become free of these current quarter responses, we can order them above interest rate and exchange rate.

Following the procedure of Bernanke et al. (2005), we follow the following steps:

1. Extracting the principal components, $F^{0}$, from the entire standardised dataset $\mathrm{X}$ (see the appendix for details about the standardisation).

2. Extracting principal components, $F^{s}$, from the slow-moving variables.

3. Regressing $F^{0}$ on $F^{s}$ interest rate and exchange rate and removing the impact of interest rate and exchange rate from $F^{0}$ to obtain $F^{n}$.

4. Regressing $X$ on $F^{n}$, interest rate and exchange rate to obtain the loadings $\lambda_{X}$ and $\lambda_{e r}$.

5. Estimating a VAR using $F^{n}$, the interest rate and exchange rate and calculating the impulse responses of the factors in response to an exchange rate shock.

6. Using the loadings from (4) and the impulse responses from (5) to calculate the impulses for all variables.

7. Bootstrapping to obtain confidence intervals.

One important question in the use of principal component of course is the number of the principal components to include. Statistical tests such as that of Bai and Ng (2002) provide criteria to determine the number of factors present in the dataset $X$. However,

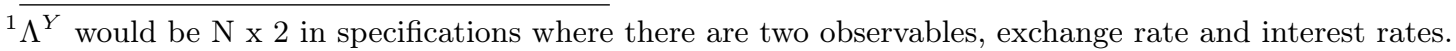


as Bernanke et al. (2005) argue, this criterion does not address the question of how many factors to include in the VAR in order to identify the shock that we are interested in. We estimate models with three, four and five factors and present all the results. However, we should caution that our sample size is rather limited on the time series dimension (1994Q3 to 2011Q2), which implies that the model may suffer from degrees of freedom issues when an additional factor (variable) is added to the VAR. ${ }^{2}$

\section{Results}

In this section, we present the results from our estimations. In section 3.1, we show the estimated principal components. In sections 3.2 to 3.5, we present impulse responses to a one per cent shock to the exchange rate. In subsection 3.6 we present the forecast error variance decompositions the historical decomposition.

\subsection{Factors}

Figure 1 shows the estimated principal components. We take an agnostic position about the factors and do not give them specific economic interpretation by grouping them into activity, prices or similar groupings. ${ }^{3}$ We find that the first principal component is highly correlated with expectations of domestic activity from the QSBO survey (trading activity and profitability) and has a 0.70 correlation with real production GDP. The second principal component is highly correlated with domestic inflation expectations ( 0.71 and 0.77 with 1 and 2 year ahead CPI inflation expectations from the RBNZ survey of expectations). Additionally, it has a correlation of 0.6 or higher with the Producer Price Index input aggregate series and some sub-components of this series namely manufacturing; construction; transport, postal, and warehousing inputs; rental, hiring, and real estate services; rental, hiring, and real estate services; and arts, recreation, and other services. Therefore, this principal component may capture price developments.

The third principal component, seems to reflect international financial and monetary conditions as it is highly correlated (above 0.5) with short term interest rates in the major western economies (Australia, US, UK, Canada and Japan, most of which make up the Trade Weighted Index that we use in our study as a measure of the exchange rate), as well as import prices of goods series (0.6). The fourth principal component seems to reflect labour market conditions in the domestic economy. It has a correlation coefficient of 0.82 with the unemployment rate, as well as being highly correlated with measures of capacity utilisation and the difficulty in finding labour. Finally, the fifth principal component appears to be more closely related to various countries' effective exchange rates. Overall, these five factors explain around 49 per cent of the total variation in the data.

It is also informative to examine what proportion of variance in some key data is explained by the estimated factors. Table 1 shows the estimated $R$-squared values for some of the variables that we include in our $X$ matrix. For the quarterly growth rate of the components of the production GDP, the factors explain as little as 3 per cent of the variation (in the

\footnotetext{
${ }^{2}$ We also estimate the model with only one observed variable and the exchange rate in the model and find very similar results. Those results are available upon request.

${ }^{3}$ Some studies (Mumtaz and Surico (2009)) pool the factors, for example, as they want to identify certain specific shocks. We have some preliminary results from such loose groupings which yielded very similar results for the exchange rate shock.
} 
Figure 1: Estimated Principal Components
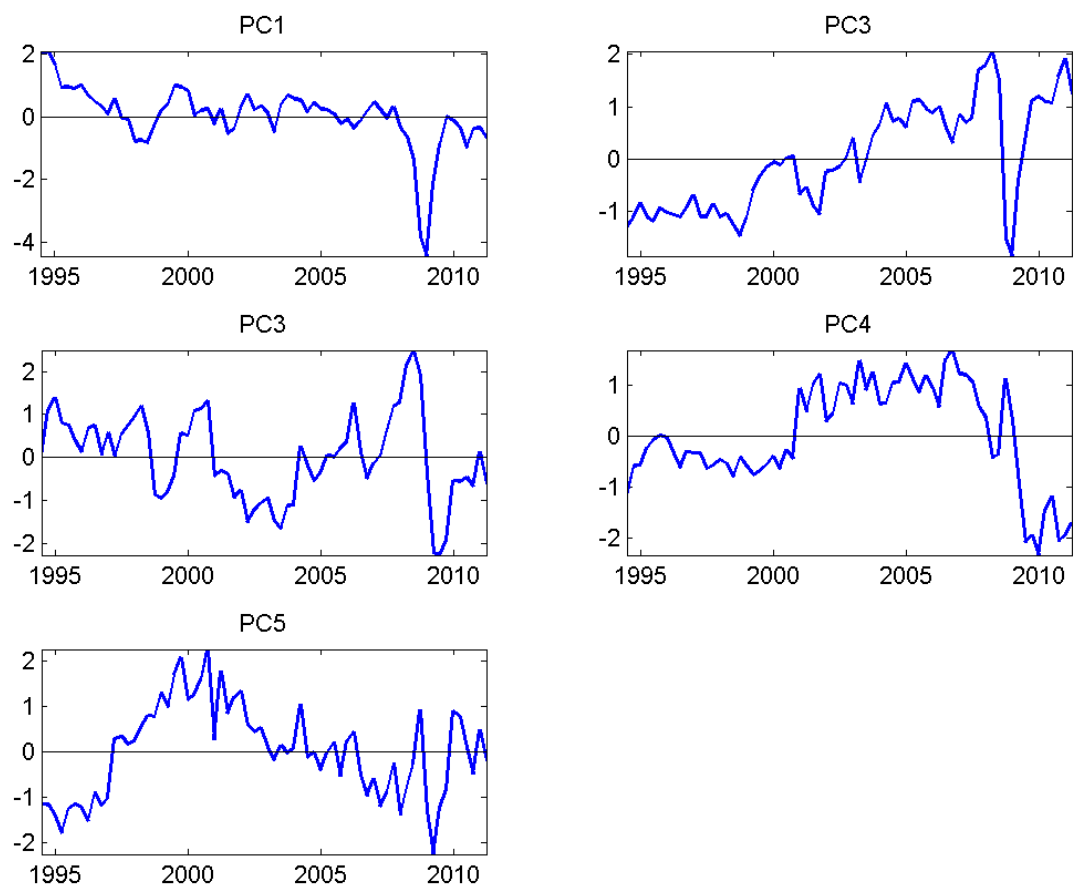

case of the agriculture sectors) to as much as 47 per cent (retail trade). The factors explain a high proportion of the variance for the following sectors: metal product manufacturing (42 per cent), transport equipment, machinery and equipment manufacturing (37 per cent), transport, postal and warehousing (32 per cent), petroleum, chemical, polymer and robber product manufacturing (27 per cent), non-metallic mineral product manufacturing (27 per cent) and construction (25 per cent) sectors. Sectors whose output is driven more by idiosyncratic drivers are agriculture (3 per cent), mining (4 per cent), electricity, gas, water and waste services (1 per cent), textile, leather, clothing and footwear manufacturing (4 per cent). Overall factors explain around 62 per cent of overall production-based real GDP.

Strong explanatory power of factors can also be observed for the components of the expenditure GDP. About 39 per cent of variance of private consumption is explained by the factors and 28 per cent in the case of investment. The factors have poor explanatory power for exports of goods, consistent with the findings for the agriculture sector mentioned above, which has been shown to be more driven by climatic conditions (Buckle et al. (2007)). About 16 per cent of variance of exports of services can be explained by the factors, while both goods and services imports are explained reasonably well (20 and 28 per cent, respectively). Interestingly, permanent and long term arrivals are mainly idiosyncratic, while the permanent and long term departures have a large common driver from these factors (27 per cent). The factors can also explain a large fraction of house price movements in New Zealand.

The factors also do a decent job in explaining some of the international variables we have in our model, including foreign GDP, where they explain between 32 per cent (in China) 
and 62 per cent (Canada) of the variation. ${ }^{4}$

Table 1: R-squared of Factors for Selected Variables

\begin{tabular}{|c|c|c|c|}
\hline Variable & $3 \mathrm{~F}$ & $4 \mathrm{~F}$ & $5 \mathrm{~F}$ \\
\hline GDP,Agriculture & 0.02 & 0.02 & 0.03 \\
\hline GDP,Forestry and Logging & 0.07 & 0.09 & 0.09 \\
\hline $\begin{array}{l}\text { GDP,Fishing, Aquaculture and Agriculture, Forestry and Fishing Support } \\
\text { Services }\end{array}$ & 0.05 & 0.06 & 0.06 \\
\hline GDP,Mining & 0.01 & 0.01 & 0.02 \\
\hline GDP,Food, Beverage and Tobacco Product Manufacturing & 0.15 & 0.15 & 0.15 \\
\hline GDP,Textile, Leather, Clothing and Footwear Manufacturing & 0.04 & 0.04 & 0.04 \\
\hline GDP,Wood and Paper Products Manufacturing & 0.16 & 0.17 & 0.17 \\
\hline GDP,Printing & 0.12 & 0.12 & 0.13 \\
\hline GDP,Petroleum, Chemical, Polymer and Rubber Product Manufacturing & 0.07 & 0.09 & 0.09 \\
\hline GDP,Non-Metallic Mineral Product Manufacturing & 0.24 & 0.25 & 0.27 \\
\hline GDP,Metal Product Manufacturing & 0.36 & 0.39 & 0.42 \\
\hline GDP,Transport Equipment, Machinery and Equipment Manufacturing & 0.32 & 0.35 & 0.37 \\
\hline GDP,Furniture and Other Manufacturing & 0.14 & 0.13 & 0.16 \\
\hline GDP,Electricity, Gas, Water and Waste Services & 0.00 & 0.01 & 0.01 \\
\hline GDP,Construction & 0.20 & 0.25 & 0.25 \\
\hline GDP,Wholesale Trade & 0.06 & 0.07 & 0.08 \\
\hline GDP,Retail Trade & 0.43 & 0.45 & 0.46 \\
\hline GDP,Accommodation and Food Services & 0.08 & 0.08 & 0.08 \\
\hline GDP,Transport, Postal and Warehousing & 0.30 & 0.30 & 0.32 \\
\hline GDP,Information Media and Telecommunications & 0.09 & 0.09 & 0.10 \\
\hline GDP,Financial and Insurance Services & 0.11 & 0.30 & 0.35 \\
\hline GDP,Rental, Hiring and Real Estate Services & 0.22 & 0.28 & 0.28 \\
\hline GDP,Professional, Scientific and Technical Services & 0.04 & 0.06 & 0.06 \\
\hline GDP,Administrative and Support Services & 0.11 & 0.12 & 0.13 \\
\hline GDP,Local Government Administration & 0.08 & 0.21 & 0.33 \\
\hline GDP,Central Government Administration, Defence and Public Safety & 0.02 & 0.12 & 0.12 \\
\hline GDP,Education and Training & 0.12 & 0.12 & 0.16 \\
\hline GDP,Health Care and Social Assistance & 0.12 & 0.13 & 0.13 \\
\hline GDP,Arts and Recreation Services & 0.09 & 0.09 & 0.11 \\
\hline GDP,Other Services & 0.16 & 0.17 & 0.19 \\
\hline FTE Total All Industries & 0.15 & 0.18 & 0.21 \\
\hline Wage Total All Industries & 0.13 & 0.25 & 0.28 \\
\hline Private Consumption & 0.34 & 0.37 & 0.39 \\
\hline Government Consumption & 0.02 & 0.02 & 0.02 \\
\hline Private Investment & 0.30 & 0.32 & 0.32 \\
\hline Government Investment & 0.00 & 0.01 & 0.01 \\
\hline Total Investment & 0.25 & 0.28 & 0.28 \\
\hline Imports of Goods & 0.20 & 0.20 & 0.20 \\
\hline Imports of Services & 0.26 & 0.26 & 0.28 \\
\hline Total Imports & 0.28 & 0.28 & 0.28 \\
\hline Exports of Goods & 0.03 & 0.03 & 0.04 \\
\hline Exports of Services & 0.07 & 0.08 & 0.16 \\
\hline Total Exports & 0.07 & 0.07 & 0.11 \\
\hline Real Production GDP & 0.58 & 0.61 & 0.62 \\
\hline Perm \& long-term migration - arrivals s.a. & 0.01 & 0.01 & 0.02 \\
\hline Perm \& long-term migration - departures s.a. & 0.23 & 0.27 & 0.27 \\
\hline HPI Total NZ (for houses) & 0.43 & 0.60 & 0.74 \\
\hline Australia: Gross Domestic Product (SA, Mil.Chn.Q3:09-Q2:10.A\$) & 0.13 & 0.14 & 0.16 \\
\hline EA 17: Gross Domestic Product (SA/WDA, Mil.Chn.2005.Euros) & 0.42 & 0.43 & 0.52 \\
\hline Canada: Gross Domestic Product (SAAR, Mil.Chn.2002.C\$) & 0.41 & 0.44 & 0.61 \\
\hline Japan: Gross Domestic Product (SAAR, Bil.Chn.2005.Yen) & 0.43 & 0.43 & 0.45 \\
\hline U.K.: Gross Domestic Product (SA, Mil.Chained.2008.Pounds) & 0.55 & 0.56 & 0.58 \\
\hline U.S.: Gross Domestic Product (SAAR, Bil.Chn.2005\$) & 0.40 & 0.42 & 0.45 \\
\hline
\end{tabular}

\footnotetext{
${ }^{4}$ The full version of the Table 1 is available upon request.
} 
Table 1: R-squared of Factors for Selected Variables

\begin{tabular}{llll} 
Variable & $3 \mathrm{~F}$ & $4 \mathrm{~F}$ & $5 \mathrm{~F}$ \\
\hline \hline China: Gross Domestic Product (SA, Bil.2000.Yuan) & 0.16 & 0.17 & 0.32 \\
\hline \hline
\end{tabular}

\subsection{Impulse Responses}

We begin by examining the impact of a one per cent shock to the nominal exchange rate (RTWI) on output, inflation and the interest rate when using different numbers of factors (figure 2). All the models yield very similar results. In response to an unexpected positive exchange rate shock (appreciation), we see a fall in inflation partly reflecting the falling tradable prices. Although the fall in inflation would have a positive real income effect, the negative effect of the exchange rate appreciation on activity dominates the positive income effect, and as a result output declines. This decline in activity leads to the fall in non-tradable prices. In response to the fall in both output and inflation the interest rates fall as well. Next, we turn to looking at the impact of the exchange rate shock on different production sectors.

Figure 2: Main Macro Variables
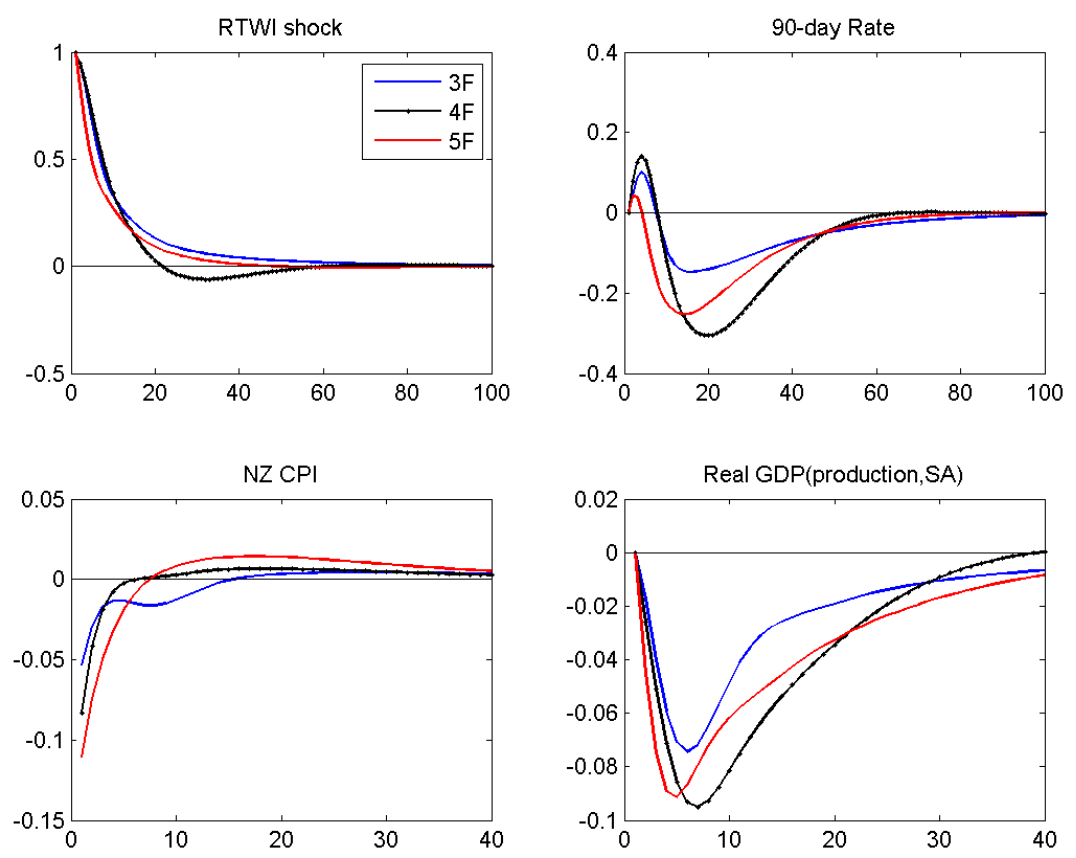

\subsection{GDP Components in Volumes}

\section{Manufacturing Sector}

Figures 3-5 show the impulse responses at sectoral level and Table 3 in the appendix shows the peak responses and level of significance for different sectors and macro variables. All manufacturing sub-sectors respond negatively to a positive exchange rate shock. The peak 
impact occurs between five to seven quarters, depending on the sub-sector. Further, the peak and the total impact are larger than in the agriculture and mining sectors (discussed below). The largest effect in the sub-components of the manufacturing category is observed in non-metallic mineral product manufacturing, with a peak impact of around 0.3 per cent. Printing; and textile, leather, clothing and footwear manufacturing also experience significant falls of around 0.2 per cent falls in activity. Producers in these sectors tend to be less differentiated or may have to compete against imported products, which may make it more difficult to compete against them when the exchange rate favours imported products.

\section{Agriculture and Mining Sector}

The aggregate fishing, aquaculture and agriculture, forestry and fishing support services sector shows a decline in volumes in response to an exchange rate shock. The fall is larger in models with four and five factors at around 0.1 per cent. Further, the effect is much more persistent and only returns back to zero towards after about 30 quarters. The mining sector experiences a slow fall in volumes, with the peak impact occuring three to four quarters after the initial shock, and it returns back to zero quickly thereafter. Although the impact is very small and insignificant, the agriculture subsector shows a slight increase in volumes in response to a one per cent exchange rate shock (appreciation), which peaks four quarters after the shock.

Figure 3: Sectoral Output
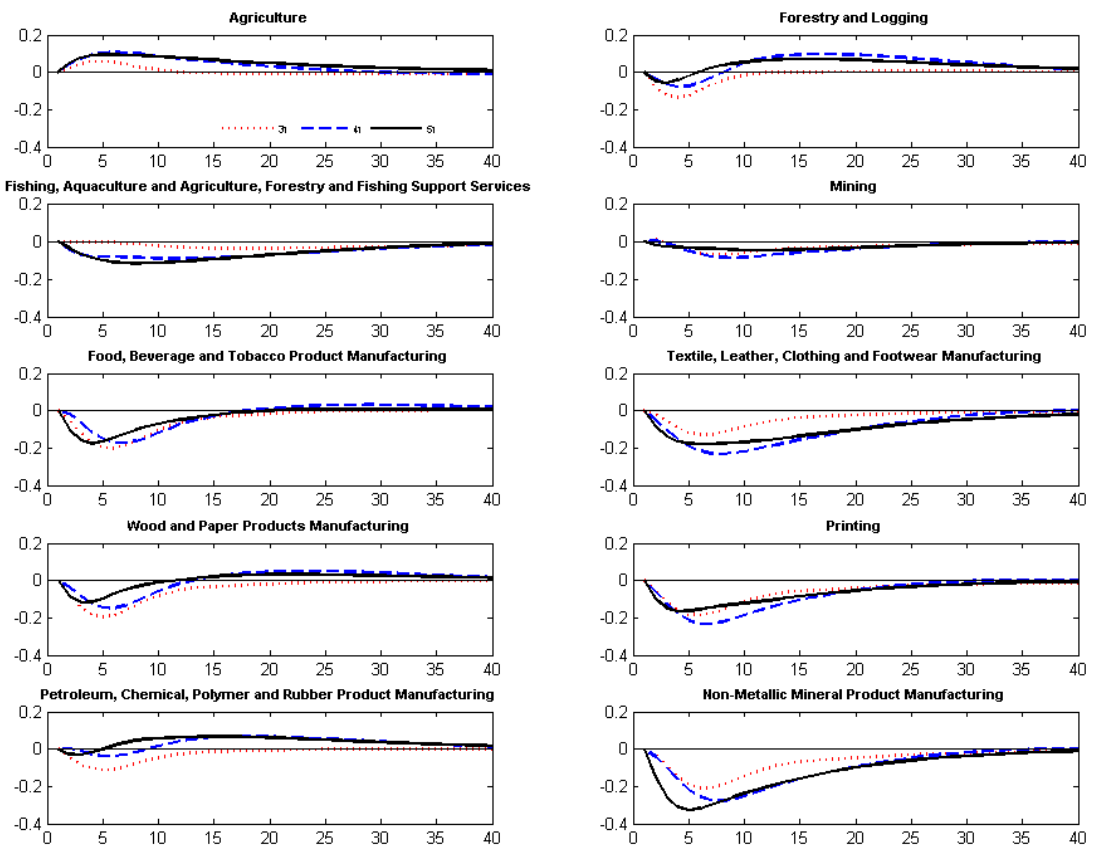
Figure 4: Sectoral Output
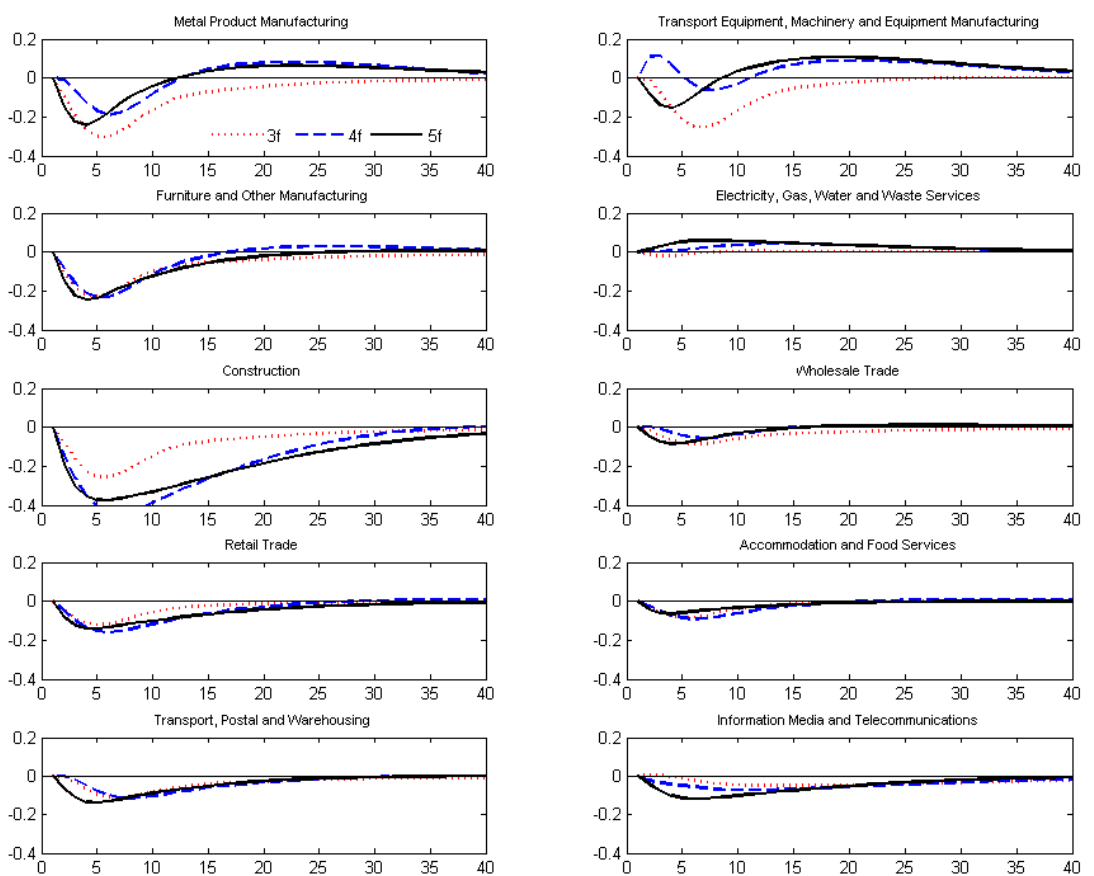

Figure 5: Sectoral Output
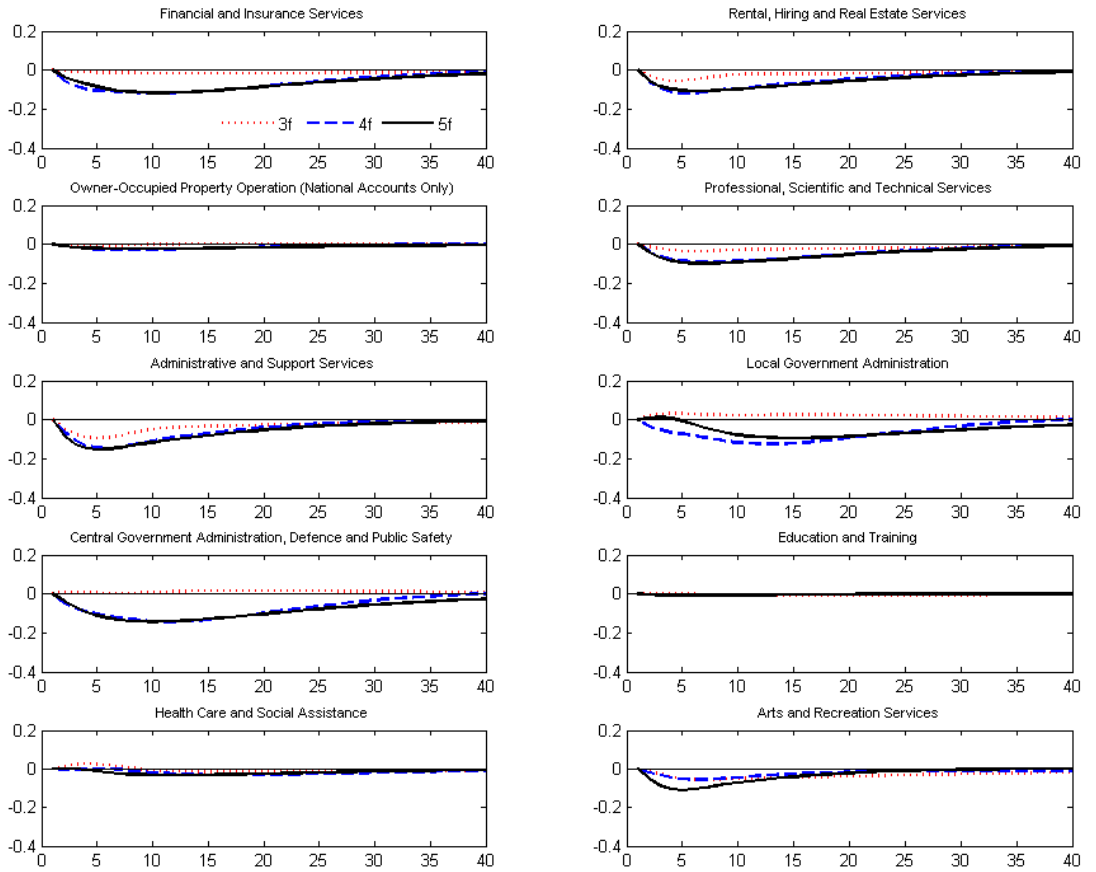


\section{Local Government, Government, Education and Health}

We observe some positive, albeit very small, responses in local and central government output. Central government expenditure in particular might increase to stimulate the economy as the exchange rate starts affecting demand. However, these responses are largely not statistically significant.

\section{Wholesale and Retail Trade}

Figure 4 shows that both the wholesale and the retail trade fall in response to an unexpected exchange rate appreciation. The fall in volumes in these sectors reflects the reduction in demand in the economy. Nonetheless, the decline is smaller than the fall in the manufacturing sector, which is the most adversely affected. This is because both sectors includes some imported content, so exchange rate appreciation would lead to some expenditure switching from domestically produced goods to foreign produced goods.

\section{Utilities and Transport}

The results for electricity, gas, water and waste services are sensitive to the number of factors in the estimation. In the three factor model, one observes a slight fall in value added, while the other models lead to a very small increase. Transport, postal and warehousing services also show a fall in output reflecting the slow down in domestic activity.

\section{Construction}

The results show that the activity in construction sector declines in response to an exchange rate appreciation. Although this may seem surprising at first, the model allows us to identify a potential transmission mechanism behind it (see Figure 6). We describe the transmission to the construction sector as follows. An unexpected appreciation (depreciation) of the exchange rate leads to a deterioration (improvement) in the relative prospects of the economy. Weaker (stronger) employment prospects see permanent and long term departures increase (decrease) significantly. This is consistent with departures data, in particular the departures to Australia (which are the largest proportion of total departures) being very sensitive to the relative business cycles between the two economies $(?)$. At the same time, permanent and long term arrivals show some decline although this is smaller than that of departures. Therefore, net permanent and long term migration falls in response to the exchange rate shock. This change in the population dynamics of the economy leads to a fall in house prices, as well as many of the forward looking confidence measures of the domestic economy. As a result, the construction sector and some other non-tradable sectors are adversely affected.

The endogenous and cyclical nature of migration has been a long established fact that dates back to the 1980s (Brosnan and Poot (1987)). Net permanent and long term migration between the two countries is correlated with relative business cycles and labour markets between New Zealand and Australia. Since net migration accounts for a large proportion of population growth, the endogenous nature of net migration leads to changes in population growth. Hence this would affect the economy in a different way than in a model where the population dynamics do not respond to shocks. While the endogenous nature of net 
migration is widely cited in New Zealand, to our knowledge, it has not been documented as an endogenous transmission mechanism in a macroeconomic model. We believe this channel deserves further attention in the face of other shocks.

Figure 6: Net Migration and Housing Market
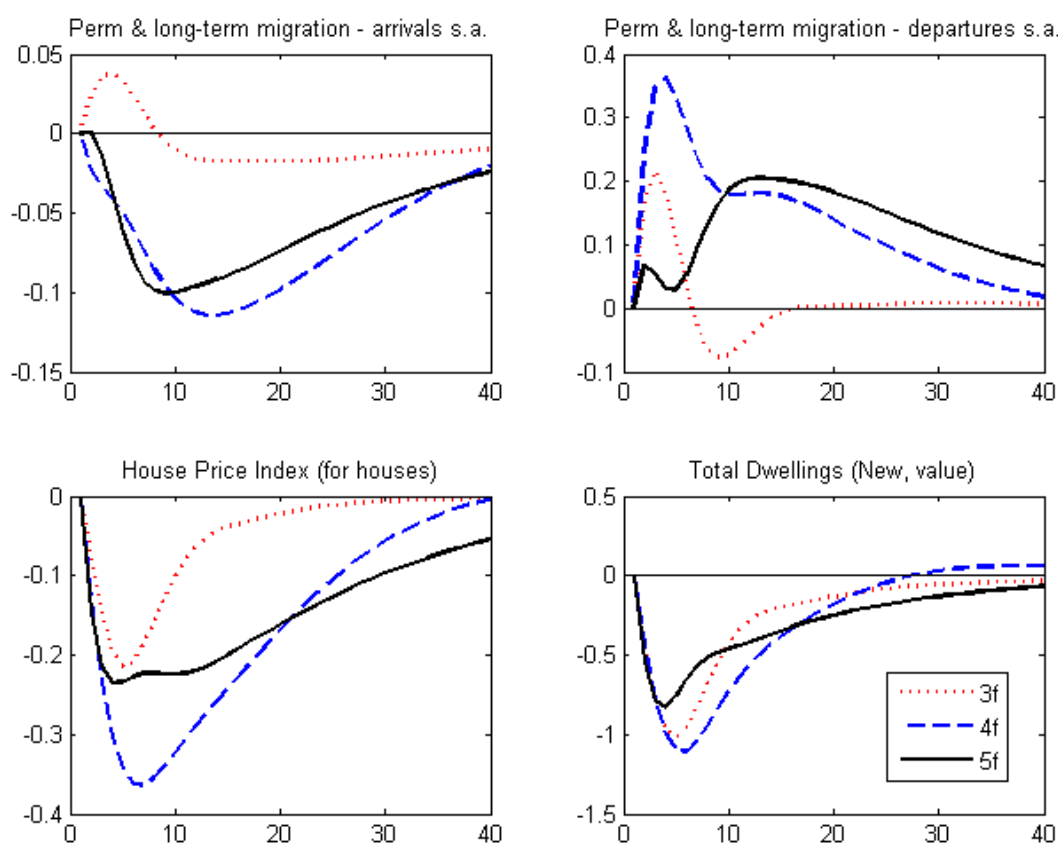

\section{Services}

Significant declines in activity are observed in the accommodation and food, administrative and support services; and the rental hiring and real estate services sectors following an exchange rate shock. However, even the largest decline still has a peak impact that is less than 0.1 per cent. Given the importance of the tourism sector to the accommodation services sector, the fall in this sector may reflect the impact of foreign tourists who might delay or reduce their holiday/spending in the face of a more expensive New Zealand dollar. Moreover, domestic consumers might also choose to switch to an overseas holiday instead of a domestic one, resulting in further decline in output in this sector. A fall in population due to migration, as we outlined above, would mean less demand for housing/rentals reducing the output of the rental hiring and real estate services sector.

\subsection{GDP Components - Consumption and Investment}

Figure 7 shows the impulse responses of some components of the expenditure GDP. Both private consumption and private investment fall in response to the exchange rate shock. But private consumption falls by a very small amount compared to private investment this reflects the relatively higher import component of private consumption. The fall in consumption is consistent with the fall in output and house prices, which are important drivers of consumption. De Veirman and Dunstan (2011), for example, show a significant 
link from house prices to consumption in New Zealand. The fall in private investment is also consistent with the fall in construction sector output and house prices, as well the fall in aggregate demand.

Figure 7: Expenditure GDP Components
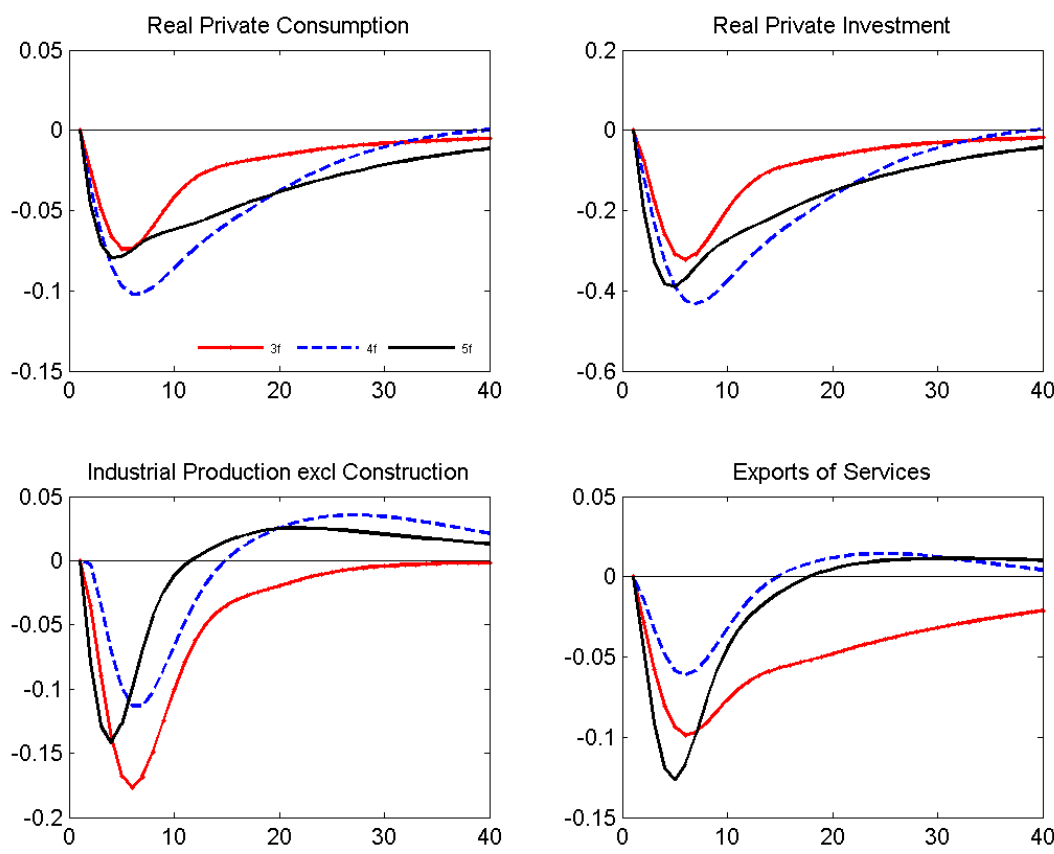

\subsection{Labour Markets}

Figure 8 shows the impulse responses of some labour market indicators. The seasonally adjusted unemployment rate increases in all models in response to the exchange rate shock. The peak impact ranges between 0.2 and 0.5 percent, depending on the number of factors used. The peak effect unemployment occurs after five to eight quarters, depending on the model, which is consistent with the notion that the unemployment rate is a lagging indicator of activity. Actual hours worked, total labour force and labour force participation rates all fall in response to the shock. Figure 9 also reveals interesting results about employment at a disaggregated level. Most of these employment results are consistent with the output responses of the same sectors. Manufacturing, forestry and mining, retail trade and construction all experience a fall in employment. Employment in some nontradable sectors such as education and training, health care and social assistance are not sensitive to the exchange rate shock, however.

\subsection{Variance and Historical Decompositions}

The VAR framework can be used to answer the question of whether the exchange rate plays a shock absorber role in an economy(Farrant and Peersman (2006), Mumtaz and SunderPlassmann (2010)). One way of answering this question is to look at the forecast error variance decompositions. Forecast error decompositions seek to identify the proportion of 
Figure 8: Labour Markets
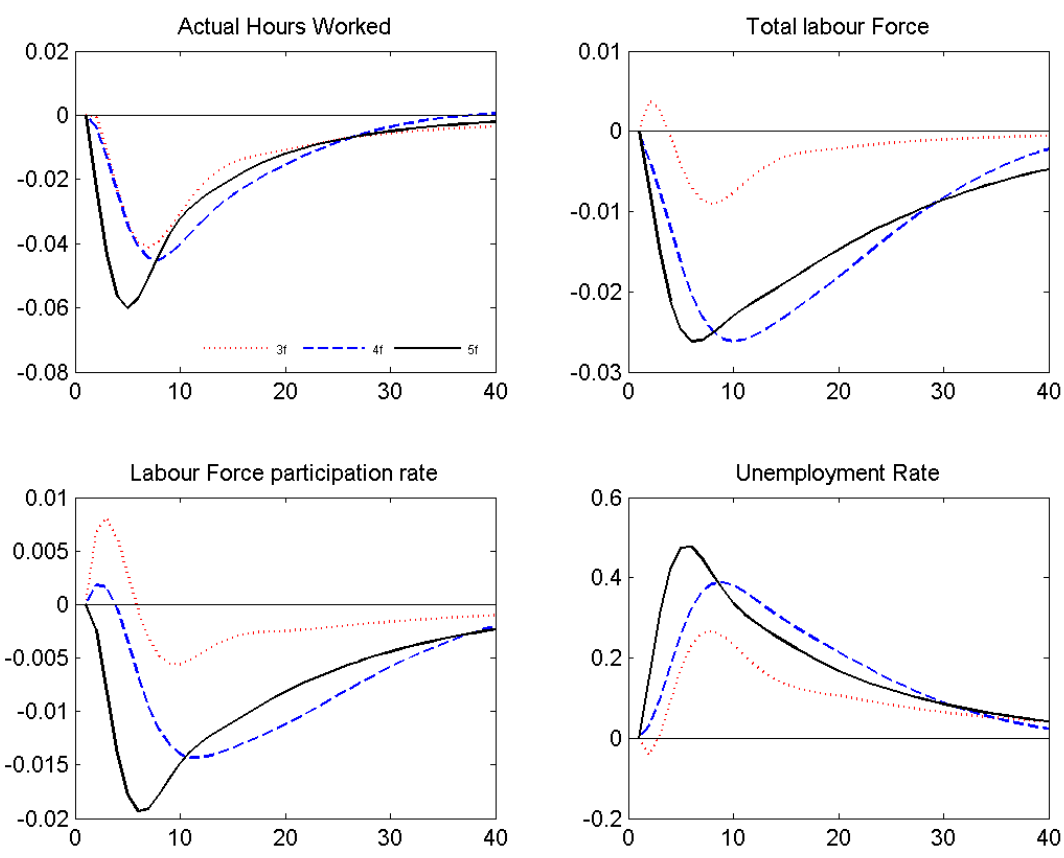

forecasting error of a variable at a particular horizon that is due to a particular shock; in our case, the factors, the interest rate and the exchange rate itself. Table 2 below presents the percentage of forecast error variances that is due to exchange rate shocks, at different horizons for the models with three, four and five factors respectively. In the very short term forecast errors in the exchange rate are mainly explained by shocks to the exchange itself; with the forecast error variance decreasing from 46 per cent to 34 per cent as we increase the number of factors in the model. At longer horizons, the forecast error due to exchange rate shocks declines to between 9 and 23 per cent. In other words, at the 40 quarter horizon between 9 to 23 per cent of the exchange rate forecast errors are due to the shocks to the exchange rate while between 77 to 91 per cent of forecast error variance is due to the other shocks.

By looking at the Table 2 one may be tempted to conclude that without own exchange rate shocks the exchange rate would have been slightly different over the sample, but not significantly different. In other words economic drivers explain the largest part of the movement in the exchange rate. However we caution such an explanation. This is because any speculative behaviour on behalf of FX markets that is correlated with any variables in our $\mathrm{X}$ dataset and therefore factors is not captured as an exchange rate shock but as explained by the factors. To use an example, take speculative search for yield this will be correlated with domestic and international interest rates in our dataset and therefore factors. Therefore movements in the exchange rate owing to yield search will be (partly) explained by the factors (and anything that is explained by the factors we term as an economic driver) and will not show up completely as an exchange rate shock in our forecast error decomposition. Hence our estimates of the role non-economic drivers explaining the exchange rate (as represented by the estimated own exchange rate shocks) represent the minimum estimate. 
Figure 9: Sectoral Employment
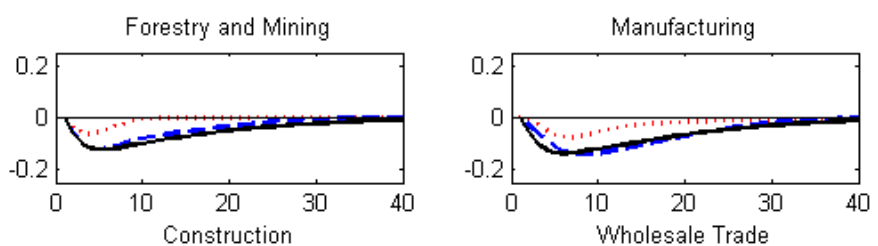

Electricity, Gas, Water and Waste Services
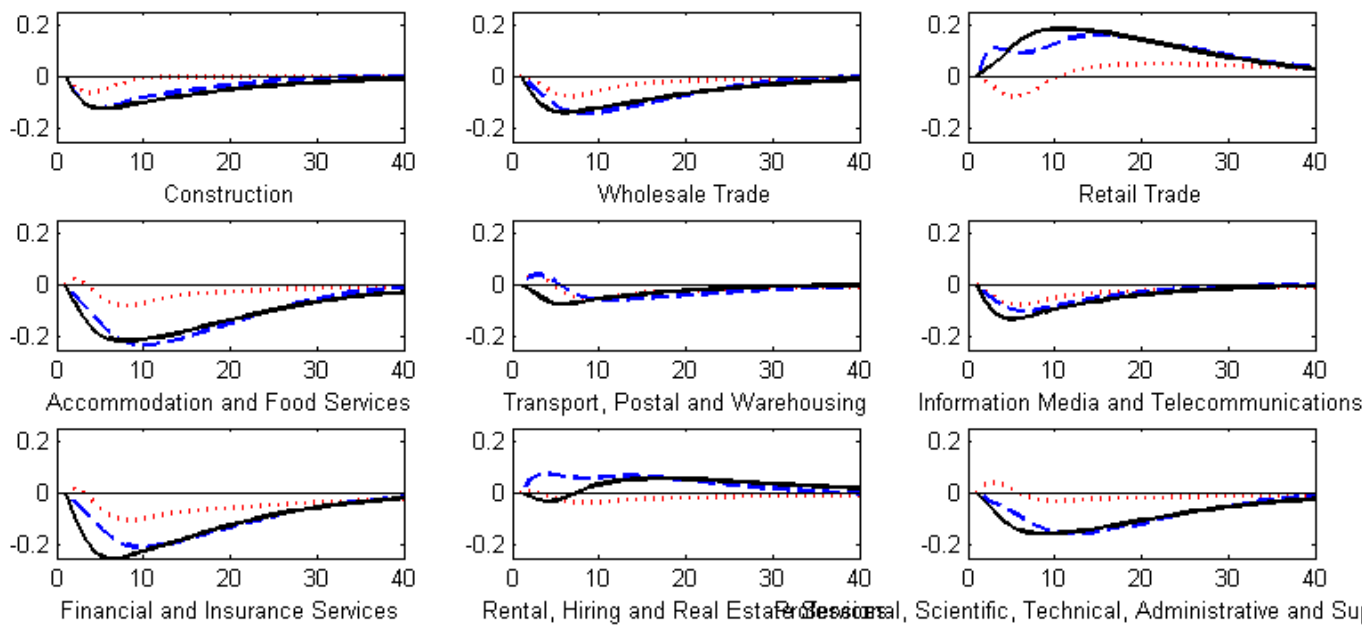

nformation Media and Telecommunications
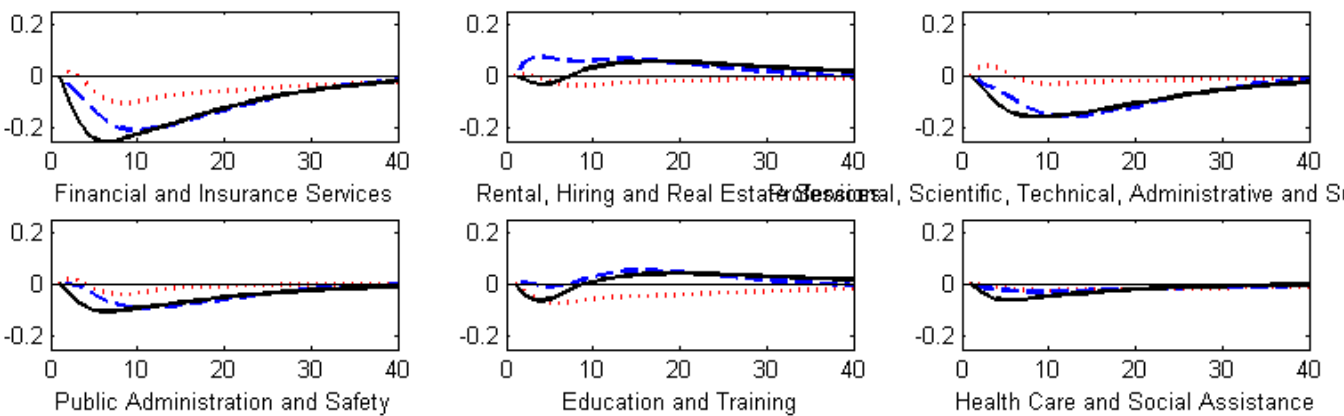

Rental, Hiring and Real Estaferdesiomer
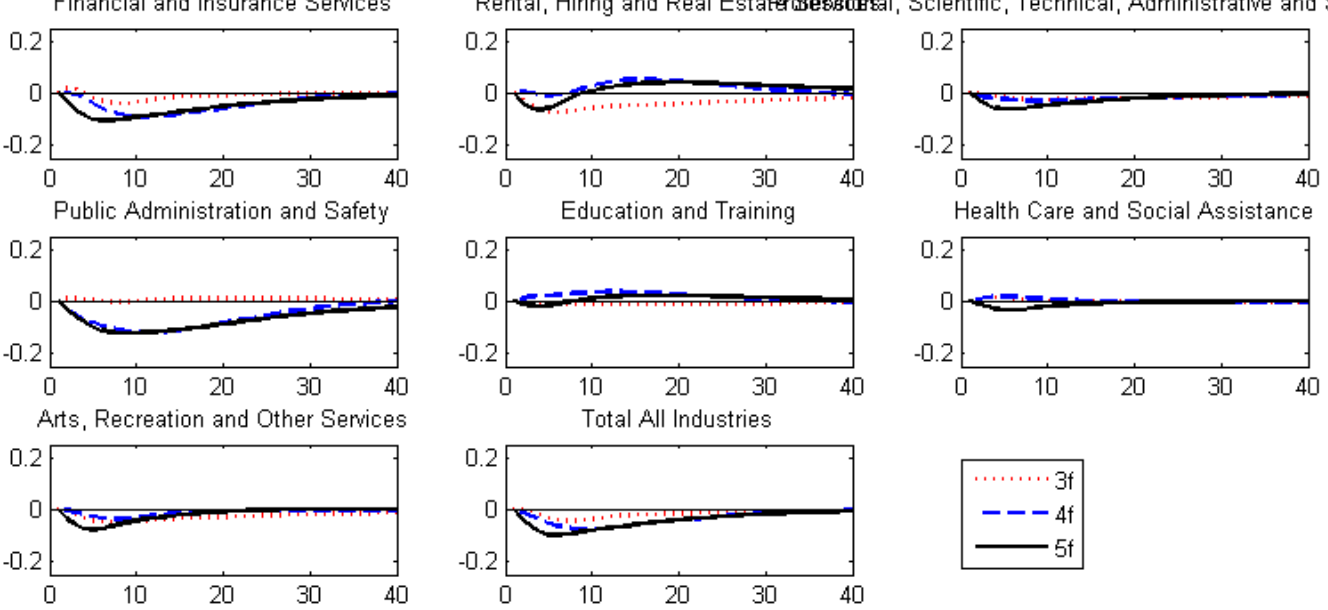
Finally we estimate a"standard" VAR with the exchange rate, interest rate, GDP and the $\mathrm{CPI}$ and found the proportion of the exchange rate shock in the variance decomposition is 92 per cent and 56 per cent at 1 and 40 quarters respectively; this compares with 34 per cent and 9 per cent in the FAVAR with 5 factors. We believe this is due to the fact that the enlarged information set we use is significantly closer to the information set that the markets use in determining the exchange rate. This can also be seen from the Table 2 where the additional use of information (i.e. more number of factors) changes the results in favour of the shock absorber story further. However, as we discussed above, this additional information may well include non-fundamental/economic related reaction on behalf of the FX markets and hence our results may well represent the minimum of the source of shock role for the New Zealand dollar.

Table 2: Forecast Error Variance Decomposition

\begin{tabular}{llll} 
Horizon & 3 Factors & 4 Factors & 5 Factors \\
\hline \hline 1 & 46 & 38 & 34 \\
10 & 25 & 23 & 10 \\
20 & 24 & 21 & 9 \\
40 & 23 & 20 & 9 \\
\hline \hline
\end{tabular}

The historical decomposition of the exchange rate tells the same story developed in the previous section. Figure 10 shows the results obtained from the five-factor model and indicates that without own exchange rate shocks, the exchange rate would have been slightly different over the sample, but not significantly different. Said differently, observed variables explain the largest part of the movement in the exchange rate, under this model. Although we reiterate our caution about the limitations of our approach in detecting noneconomic drivers of the exchange rate.

Figure 10: Historical Decomposition

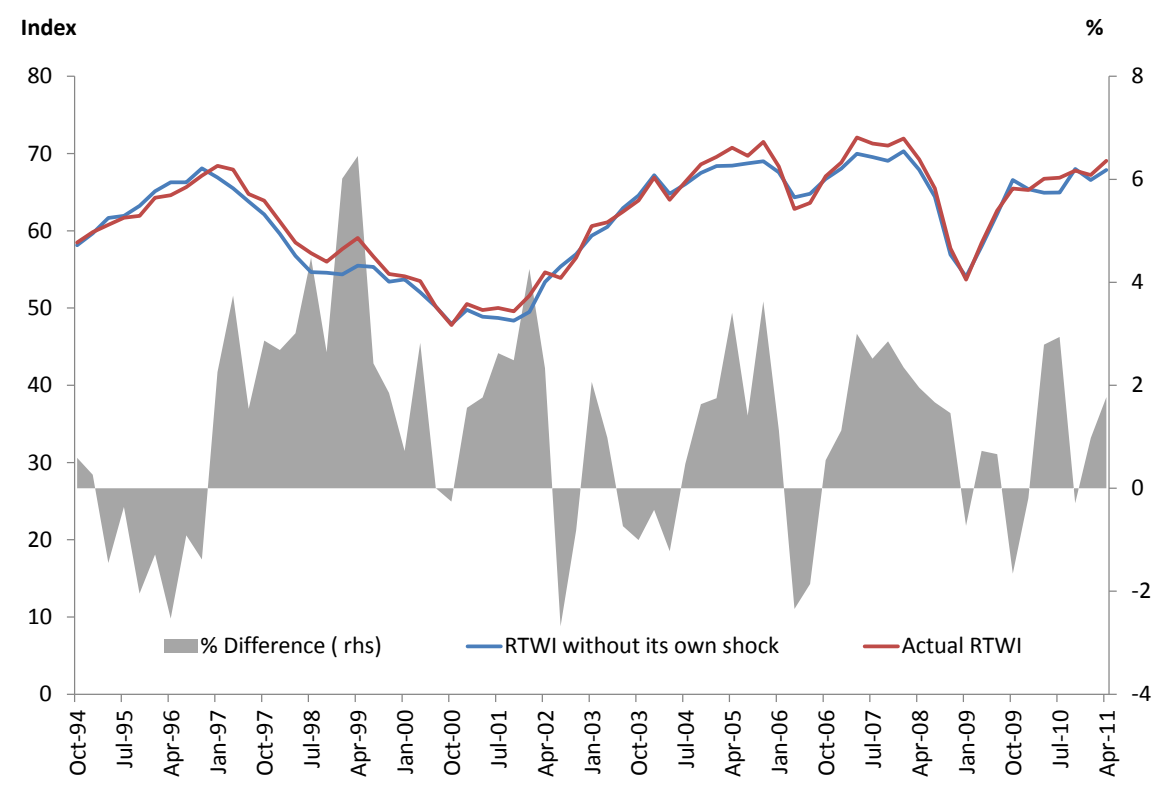




\section{Conclusions}

In this paper, we estimated a factor augmented vector autoregression (FAVAR) to identify exchange rate shocks and assessed the transmission of these shocks to the economy at the sectoral level. We have two major findings in our paper. First, exchange rate shocks have a significant and negative impact on the tradable sectors of the economy. The manufacturing sector is the most adversely affected by exchange rate shocks. We find that the agricultural sector is not affected to a large extent by such shocks, which is consistent with earlier research Buckle et al. (2007) showing that developments in New Zealand's pastoral sector tend to be driven by climatic shocks over the short term. Second, an exchange rate shock also has significant effects on the non-tradable sectors as well. We provided a possible explanation and evidence that focuses on the relationship between New Zealand's relative business cycle, migration dynamics, housing and the broader economy. Although we find significant role for shock absorber nature for the New Zealand dollar exchange rate, we believe however, our model does not adequately capture the speculative or non-rational behaviour to be adequately answer this question.

\section{References}

Artis, M. and M. Ehrmann (2006, October). The exchange rate - a shock-absorber or source of shocks? a study of four open economies. Journal of International Money and Finance 25(6), 874-893.

Bai, J. and S. Ng (2002, January). Determining the number of factors in approximate factor models. Econometrica 70(1), 191-221.

Bernanke, B., J. Boivin, and P. S. Eliasz (2005, January). Measuring the effects of monetary policy: A factor-augmented vector autoregressive (favar) approach. The Quarterly Journal of Economics 120(1), 387-422.

Brosnan, P. and J. Poot (1987). Modelling the determinants of trans-tasman migration after world war ii. Economic Record 63, 313-29.

Buckle, R. A., K. Kim, H. Kirkham, N. McLellan, and J. Sharma (2007). A structural var business cycle model for a volatile small open economy. Economic Modelling 24(6), 990 -1017 .

Buiter, W. H. (2000, August). Optimal currency areas: Scottish economic society/royal bank of scotland annual lecture, 1999. Scottish Journal of Political Economy 47(3), $213-50$.

De Veirman, E. and A. Dunstan (2011, July). Time-varying returns, intertemporal substitution and cyclical variation in consumption. The B.E. Journal of Macroeconomics 11(1), 1-41.

Fabling, R. and L. Sanderson (2013). Export performance, invoice currency, and heterogeneous exchange rate pass-through. Reserve Bank of New Zealand Discussion Paper (01).

Farrant, K. and G. Peersman (2006, June). Is the exchange rate a shock absorber or a source of shocks? new empirical evidence. Journal of Money, Credit and Banking 38(4), 939-961. 
Hahn, E. (2007). The impact of exchange rate shocks on sectoral activity and prices in the euro area. European Central Bank Working Paper (796).

Haug, A. A. and C. Smith (2007, April). Local linear impulse responses for a small open economy. Reserve Bank of New Zealand Discussion Paper Series DP2007/09, Reserve Bank of New Zealand.

Mumtaz, H. and L. Sunder-Plassmann (2010, March). Time-varying dynamics of the real exchange rate. a structural var analysis. Bank of England working papers 382, Bank of England.

Mumtaz, H. and P. Surico (2009, 02). The transmission of international shocks: A factoraugmented var approach. Journal of Money, Credit and Banking 41(s1), 71-100.

Salter, W. (1959). Internal and external balance: The role of expenditure effects. Economic Record 35(71), 226-238.

Swan, T. (1955). Longer run problems of the balance of payments', in The Australian Economy: A Volume of Readings. Melbourne: Cheshire Press.

\section{Appendix}

\subsection{Data and Transformation}

We use data from various sources. New Zealand data is sourced mainly from Statistics New Zealand and the Reserve Bank of New Zealand, whilst international data from the respective national statistics agencies. Most of the data is retrieved using HAVER. Table 3 in the appendix lists all the data used in the estimation as well as the transformation applied to each raw data. Prior to the estimation, all variables are demeaned and standardised. We use quarterly data covering the period 1994Q3 to 2011Q2. The sample is mainly imposed by New Zealand data availability.

There are 194 domestic variables and 110 international variables. We have heavily weighted the dataset towards New Zealand variables for two reasons. One, given our research question is to look at the sectoral impacts of the exchange rate, we include a lot of disaggregated sectoral GDP components from production GDP to examine how the exchange rate impact varies across them; further we include, amongst other things, commodity price, labour market and survey data, as well as a range of financial variables, to understand the channels through which the exchange rate shock transmits to these sectors.

Our international data is composed of data from the US and major world economies namely Australia, Canada, China, Japan, the UK and aggregated measures for the seventeen countries of the Euro area. This dataset covers a broad range of macroeconomic and financial variables for these countries: GDP, industrial production, unemployment, interest rates, inflation, stock prices and exchange rates for example.

We use the nominal trade weighted exchange rate as our exchange rate of choice. The trade weighted index is the nominal exchange rates of our major trading partners - US, Japan, Australia, the UK and the Euro countries, weighted 50/50 by New Zealand's trade with these countries and these countries nominal GDPs (in US dollars). We chose the trade weighted index rather than a specific cross rate because, as Fabling and Sanderson (2013) show, New Zealand exporters invoice in a variety of currencies - in particular, the 
New Zealand, US and the Australian dollar. We use the nominal exchange rather than the real exchange rate as much of the policy debate has been centred on the level of the nominal exchange rate (for example, Wheeler, 2013); the key results are robust to using the real exchange rate however.

Column three shows the transformations used (1 for no transformation, 2 for first difference, 4 for natural logarithm, 5 for first difference of natural logarithm). Asterisk in the series label denotes slow moving variables. 
Table 3: Data

\begin{tabular}{|c|c|c|c|}
\hline $\begin{array}{l}\text { Variable num- } \\
\text { ber }\end{array}$ & Mnenomics & Transformation & Description \\
\hline 1 & $\mathrm{X} 101$ & 5 & $\begin{array}{l}\text { Gross domestic product: Agriculture (SA, Chained } \\
\text { vol.1995/6, ANZSIC06 sector classification). }\end{array}$ \\
\hline 2 & X102 & 5 & $\begin{array}{l}\text { Gross domestic product: Forestry and Logging (SA, } \\
\text { Chained vol.1995/6, ANZSIC06 sector classification). }\end{array}$ \\
\hline 3 & X103 & 5 & $\begin{array}{l}\text { Gross domestic product: Fishing, Aquaculture and } \\
\text { Agriculture, Forestry and Fishing Support Services } \\
\text { (SA, Chained vol.1995/6, ANZSIC06 sector classif- } \\
\text { cation). }\end{array}$ \\
\hline 4 & X104 & 5 & $\begin{array}{l}\text { Gross domestic product: Mining (SA, Chained } \\
\text { vol.1995/6, ANZSIC96 sector classification). }\end{array}$ \\
\hline 5 & X105 & 5 & $\begin{array}{l}\text { Gross domestic product: Food, Beverage and } \\
\text { Tobacco Product Manufacturing (SA, Chained } \\
\text { vol.1995/6, ANZSIC06 sector classification). }\end{array}$ \\
\hline 6 & X106 & 5 & $\begin{array}{l}\text { Gross domestic product: Textile, Leather, Cloth- } \\
\text { ing and Footwear Manufacturing (SA, Chained } \\
\text { vol.1995/6, ANZSIC06 sector classification). }\end{array}$ \\
\hline 7 & $\mathrm{X} 107$ & 5 & $\begin{array}{l}\text { Gross domestic product: Wood and Paper Products } \\
\text { Manufacturing (SA, Chained vol.1995/6, ANZSIC06 } \\
\text { sector classification). }\end{array}$ \\
\hline 8 & X108 & 5 & $\begin{array}{l}\text { Gross domestic product: Printing (SA, Chained } \\
\text { vol.1995/6, ANZSIC06 sector classification). }\end{array}$ \\
\hline 9 & X109 & 5 & $\begin{array}{l}\text { Gross domestic product: Petroleum, Chemical, } \\
\text { Polymer and Rubber Product Manufacturing (SA, } \\
\text { Chained vol.1995/6, ANZSIC06 sector classification). }\end{array}$ \\
\hline 10 & $\mathrm{X} 110$ & 5 & $\begin{array}{l}\text { Gross domestic product: Non-Metallic Mineral } \\
\text { Product Manufacturing (SA, Chained vol.1995/6, } \\
\text { ANZSIC96 sector classification). }\end{array}$ \\
\hline 11 & $\mathrm{X} 111$ & 5 & $\begin{array}{l}\text { Gross domestic product: Metal Product Manufactur- } \\
\text { ing (SA, Chained vol.1995/6, ANZSIC06 sector clas- } \\
\text { sification). }\end{array}$ \\
\hline 12 & $\mathrm{X} 112$ & 5 & $\begin{array}{l}\text { Gross domestic product: Transport Equipment, Ma- } \\
\text { chinery and Equipment Manufacturing (SA, Chained } \\
\text { vol.1995/6, ANZSIC06 sector classification). }\end{array}$ \\
\hline 13 & $\mathrm{X} 113$ & 5 & $\begin{array}{l}\text { Gross domestic product: Furniture and Other Manu- } \\
\text { facturing (SA, Chained vol.1995/6, ANZSIC96 sector } \\
\text { classification). }\end{array}$ \\
\hline 14 & $\mathrm{X} 114$ & 5 & $\begin{array}{l}\text { Gross domestic product: Electricity, Gas, Water and } \\
\text { Waste Services (SA, Chained vol.1995/6, ANZSIC0 } 6 \\
\text { sector classification). }\end{array}$ \\
\hline 15 & $\mathrm{X} 115$ & 5 & $\begin{array}{l}\text { Gross domestic product: Construction (SA, Chained } \\
\text { vol.1995/6, ANZSIC06 sector classification). }\end{array}$ \\
\hline 16 & $\mathrm{X} 116$ & 5 & $\begin{array}{l}\text { Gross domestic product: Wholesale trade (SA, } \\
\text { Chained vol.1995/6, ANZSIC06 sector classification). }\end{array}$ \\
\hline 17 & $\mathrm{X} 117$ & 5 & $\begin{array}{l}\text { Gross domestic product: Retail Trade and Accom- } \\
\text { modation (SA, Chained vol.1995/6, ANZSIC06 sector } \\
\text { classification). }\end{array}$ \\
\hline 18 & $\mathrm{X} 118$ & 5 & $\begin{array}{l}\text { Gross domestic product: Accommodation and Food } \\
\text { Services (SA, Chained vol.1995/6, ANZSIC06 sector } \\
\text { classification). }\end{array}$ \\
\hline 19 & X119 & 5 & $\begin{array}{l}\text { Gross domestic product: Transport, Postal and } \\
\text { Warehousing (SA, Chained vol.1995/6, ANZSIC06 } \\
\text { sector classification). }\end{array}$ \\
\hline 20 & $\mathrm{X} 120$ & 5 & $\begin{array}{l}\text { Gross domestic product: Information Media and } \\
\text { Telecommunications (SA, Chained vol.1995/6, } \\
\text { ANZSIC06 sector classification). }\end{array}$ \\
\hline
\end{tabular}


Table 3: Data

\begin{tabular}{|c|c|c|c|c|}
\hline $\begin{array}{l}\text { Variable } \\
\text { ber }\end{array}$ & num- & Mnenomics & Transformation & Description \\
\hline 21 & & $\mathrm{X} 121$ & 5 & $\begin{array}{l}\text { Gross domestic product: Financial and Insurance } \\
\text { Services (SA, Chained vol.1995/6, ANZSIC06 sector } \\
\text { classification). }\end{array}$ \\
\hline 22 & & $\mathrm{X} 122$ & 5 & $\begin{array}{l}\text { Gross domestic product: Rental, Hiring and Real Es- } \\
\text { tate Services (SA, Chained vol.1995/6, ANZSIC06 } \\
\text { sector classification). }\end{array}$ \\
\hline 23 & & $\mathrm{X} 123$ & 5 & $\begin{array}{l}\text { Gross domestic product: Owner-Occupied Property } \\
\text { Operation (SA, Chained vol.1995/6, ANZSIC06 sec- } \\
\text { tor classification). }\end{array}$ \\
\hline 24 & & $\mathrm{X} 124$ & 5 & $\begin{array}{l}\text { Gross domestic product: Professional, Scientific } \\
\text { and Technical Services (SA, Chained vol.1995/6, } \\
\text { ANZSIC06 sector classification). }\end{array}$ \\
\hline 25 & & $\mathrm{X} 125$ & 5 & $\begin{array}{l}\text { Gross domestic product: Administrative and Support } \\
\text { Services (SA, Chained vol.1995/6, ANZSIC06 sector } \\
\text { classification). }\end{array}$ \\
\hline 26 & & $\mathrm{X} 126$ & 5 & $\begin{array}{l}\text { Gross domestic product: Local Government Admin- } \\
\text { istration (SA, Chained vol.1995/6, ANZSIC06 sector } \\
\text { classification). }\end{array}$ \\
\hline 27 & & $\mathrm{X} 127$ & 5 & $\begin{array}{l}\text { Gross domestic product: Central Government Ad- } \\
\text { ministration, Defence and Public Safety (SA, Chained } \\
\text { vol.1995/6, ANZSIC06 sector classification). }\end{array}$ \\
\hline 28 & & $\mathrm{X} 128$ & 5 & $\begin{array}{l}\text { Gross domestic product: Education and Training } \\
\text { (SA, Chained vol.1995/6, ANZSIC06 sector classifi- } \\
\text { cation). }\end{array}$ \\
\hline 29 & & X129 & 5 & $\begin{array}{l}\text { Gross domestic product: Health Care and Social As- } \\
\text { sistance (SA, Chained vol.1995/6, ANZSIC06 sector } \\
\text { classification). }\end{array}$ \\
\hline 30 & & $\mathrm{X} 130$ & 5 & $\begin{array}{l}\text { Gross domestic product: Arts and Recreation Ser- } \\
\text { vices (SA, Chained vol.1995/6, ANZSIC06 sector } \\
\text { classification). }\end{array}$ \\
\hline 31 & & X131 & 5 & $\begin{array}{l}\text { Gross domestic product: Other Services (SA, } \\
\text { Chained vol.1995/6, ANZSIC06 sector classification). }\end{array}$ \\
\hline 32 & & $\mathrm{X} 132$ & 5 & $\begin{array}{l}\text { Full-Time Equivalent Employees - Forestry and Min- } \\
\text { ing }\end{array}$ \\
\hline 33 & & $\mathrm{X} 133$ & 5 & Full-Time Equivalent Employees - Manufacturing \\
\hline 34 & & $\mathrm{X} 134$ & 5 & $\begin{array}{l}\text { Full-Time Equivalent Employees -Electricity, Gas, } \\
\text { Water and Waste Services }\end{array}$ \\
\hline 35 & & $\mathrm{X} 135$ & 5 & Full-Time Equivalent Employees - Construction \\
\hline 36 & & $\mathrm{X} 136$ & 5 & Full-Time Equivalent Employees - Wholesale Trade \\
\hline 37 & & $\mathrm{X} 137$ & 5 & Full-Time Equivalent Employees - Retail Trade \\
\hline 38 & & $\mathrm{X} 138$ & 5 & $\begin{array}{l}\text { Full-Time Equivalent Employees Accommodation } \\
\text { and Food Services }\end{array}$ \\
\hline 39 & & X139 & 5 & $\begin{array}{l}\text { Full-Time Equivalent Employees - Transport, Postal } \\
\text { and Warehousing }\end{array}$ \\
\hline 40 & & $\mathrm{X} 140$ & 5 & $\begin{array}{l}\text { Full-Time Equivalent Employees - Information Media } \\
\text { and Telecommunications }\end{array}$ \\
\hline 41 & & $\mathrm{X} 141$ & 5 & $\begin{array}{l}\text { Full-Time Equivalent Employees - Financial and In- } \\
\text { surance Services }\end{array}$ \\
\hline 42 & & $\mathrm{X} 142$ & 5 & $\begin{array}{l}\text { Full-Time Equivalent Employees - Rental, Hiring and } \\
\text { Real Estate Services }\end{array}$ \\
\hline 43 & & $\mathrm{X} 143$ & 5 & $\begin{array}{l}\text { Full-Time Equivalent Employees - Professional, Sci- } \\
\text { entific, Technical, Administrative and Support Ser- } \\
\text { vices }\end{array}$ \\
\hline 44 & & $\mathrm{X} 144$ & 5 & $\begin{array}{l}\text { Full-Time Equivalent Employees - Public Administra- } \\
\text { tion and Safety }\end{array}$ \\
\hline 45 & & X145 & 5 & $\begin{array}{l}\text { Full-Time Equivalent Employees - Education and } \\
\text { Training }\end{array}$ \\
\hline
\end{tabular}


Table 3: Data

\begin{tabular}{|c|c|c|c|}
\hline $\begin{array}{l}\text { Variable num- } \\
\text { ber }\end{array}$ & Mnenomics & Transformation & Description \\
\hline 46 & $\mathrm{X} 146$ & 5 & $\begin{array}{l}\text { Full-Time Equivalent Employees - Health Care and } \\
\text { Social Assistance }\end{array}$ \\
\hline 47 & $\mathrm{X} 147$ & 5 & $\begin{array}{l}\text { Full-Time Equivalent Employees - Arts, Recreation } \\
\text { and Other Services }\end{array}$ \\
\hline 48 & $\mathrm{X} 148$ & 5 & $\begin{array}{l}\text { Full-Time Equivalent Employees - Total All Indus- } \\
\text { tries }\end{array}$ \\
\hline 49 & X149 & 5 & $\begin{array}{l}\text { Labour Cost Index - Salary and wages rates - Forestry } \\
\text { and Mining }\end{array}$ \\
\hline 50 & X150 & 5 & $\begin{array}{l}\text { Labour Cost Index - Salary and wages rates - Manu- } \\
\text { facturing }\end{array}$ \\
\hline 51 & $\mathrm{X} 151$ & 5 & $\begin{array}{l}\text { Labour Cost Index - Salary and wages rates - Elec- } \\
\text { tricity, Gas, Water and Waste Services }\end{array}$ \\
\hline 52 & $\mathrm{X} 152$ & 5 & $\begin{array}{l}\text { Labour Cost Index - Salary and wages rates - Con- } \\
\text { struction }\end{array}$ \\
\hline 53 & X153 & 5 & $\begin{array}{l}\text { Labour Cost Index - Salary and wages rates - Whole- } \\
\text { sale Trade }\end{array}$ \\
\hline 54 & X154 & 5 & $\begin{array}{l}\text { Labour Cost Index - Salary and wages rates - Retail } \\
\text { Trade }\end{array}$ \\
\hline 55 & $\mathrm{X} 155$ & 5 & $\begin{array}{l}\text { Labour Cost Index - Salary and wages rates - Accom- } \\
\text { modation and Food Services }\end{array}$ \\
\hline 56 & $\mathrm{X} 156$ & 5 & $\begin{array}{l}\text { Labour Cost Index - Salary and wages rates - Trans- } \\
\text { port, Postal and Warehousing }\end{array}$ \\
\hline 57 & $\mathrm{X} 157$ & 5 & $\begin{array}{l}\text { Labour Cost Index - Salary and wages rates - Infor- } \\
\text { mation Media and Telecommunications }\end{array}$ \\
\hline 58 & $\mathrm{X} 158$ & 5 & $\begin{array}{l}\text { Labour Cost Index - Salary and wages rates - Finan- } \\
\text { cial and Insurance Services }\end{array}$ \\
\hline 59 & X159 & 5 & $\begin{array}{l}\text { Labour Cost Index - Salary and wages rates - Rental, } \\
\text { Hiring and Real Estate Services }\end{array}$ \\
\hline 60 & $\mathrm{X} 160$ & 5 & $\begin{array}{l}\text { Labour Cost Index - Salary and wages rates - Profes- } \\
\text { sional, Scientific, Technical, Administrative and Sup- } \\
\text { port Services }\end{array}$ \\
\hline 61 & X161 & 5 & $\begin{array}{l}\text { Labour Cost Index - Salary and wages rates - Public } \\
\text { Administration and Safety }\end{array}$ \\
\hline 62 & $\mathrm{X} 162$ & 5 & $\begin{array}{l}\text { Labour Cost Index - Salary and wages rates - Educa- } \\
\text { tion and Training }\end{array}$ \\
\hline 63 & X163 & 5 & $\begin{array}{l}\text { Labour Cost Index - Salary and wages rates - Health } \\
\text { Care and Social Assistance }\end{array}$ \\
\hline 64 & X164 & 5 & $\begin{array}{l}\text { Labour Cost Index - Salary and wages rates - Arts, } \\
\text { Recreation and Other Services }\end{array}$ \\
\hline 65 & X165 & 5 & $\begin{array}{l}\text { Labour Cost Index - Salary and wages rates - Total } \\
\text { All Industries }\end{array}$ \\
\hline 66 & X166 & 5 & Real GDP: Imports of consumption goods (SA) \\
\hline 67 & X167 & 5 & Real GDP: Total Household Consumption (SA) \\
\hline 68 & $\mathrm{X} 168$ & 5 & Real GDP: Total Private Consumption (SA) \\
\hline 69 & $\mathrm{X} 169$ & 5 & Real GDP: Total Govt Consumption (SA) \\
\hline 70 & $\mathrm{X} 170$ & 5 & Real GDP: Private Investment Total (SA) \\
\hline 71 & $\mathrm{X} 171$ & 5 & Real GDP: Govt Investment Total (SA) \\
\hline 72 & $\mathrm{X} 172$ & 5 & Real GDP: Total Investment (SA) \\
\hline 73 & $\mathrm{X} 173$ & 5 & Real GDP: Imports Goods Total (SA) \\
\hline 74 & $\mathrm{X} 174$ & 5 & Real GDP: Imports Services (SA) \\
\hline 75 & $\mathrm{X} 175$ & 5 & Real GDP: Imports Total (SA) \\
\hline 76 & $\mathrm{X} 176$ & 5 & Real GDP: Exports of Goods (SA) \\
\hline 77 & $\mathrm{X} 177$ & 5 & Real GDP: Exports of Services (SA) \\
\hline 78 & $\mathrm{X} 178$ & 5 & Real GDP: Exports Total (SA) \\
\hline 79 & $\mathrm{X} 179$ & 5 & Real GDP: Gross National Expenditure (SA) \\
\hline 80 & $\mathrm{X} 180$ & 5 & Real Production GDP: Manufacturing Total (SA) \\
\hline 81 & $\mathrm{X} 181$ & 5 & Real GDP: Total Production GDP \\
\hline
\end{tabular}


Table 3: Data

\begin{tabular}{|c|c|c|c|}
\hline $\begin{array}{l}\text { Variable num- } \\
\text { ber }\end{array}$ & Mnenomics & Transformation & Description \\
\hline 82 & $\mathrm{X} 182$ & 5 & $\begin{array}{l}\text { Real Retail Sales: All industries total (SA, Treasury } \\
\text { backdate) }\end{array}$ \\
\hline 83 & $\mathrm{X} 183$ & 5 & $\begin{array}{l}\text { Real GDP: Private Investment: Dwellings (SA, } \\
\text { RBNZ estimates) }\end{array}$ \\
\hline 84 & X184 & 1 & Employment: Total (SA, HLFS) \\
\hline 85 & $\mathrm{X} 185$ & 1 & Unemployment: Total (SA, HLFS) \\
\hline 86 & $\mathrm{X} 186$ & 5 & $\begin{array}{l}\text { Total number of actual hours worked each week (SA, } \\
\text { HLFS) }\end{array}$ \\
\hline 87 & $\mathrm{X} 187$ & 5 & $\begin{array}{l}\text { Total number of usual hours worked each week (SA, } \\
\text { HLFS) }\end{array}$ \\
\hline 88 & $\mathrm{X} 188$ & 5 & Total labour force (SA, HLFS) \\
\hline 89 & X189 & 5 & Total not in labour force (SA, HLFS) \\
\hline 90 & $\mathrm{X} 190$ & 5 & Labour force participation rate: Total (SA, HLFS) \\
\hline 91 & X191 & 1 & Unemployment rate: Total (SA, HLFS) \\
\hline 92 & $\mathrm{X} 192$ & 5 & Total gross earnings (SA, QES) \\
\hline 93 & X193 & 5 & $\begin{array}{l}\text { Filled jobs (Full-time paid employment): Total (SA, } \\
\text { QES) }\end{array}$ \\
\hline 94 & X194 & 5 & Total paid hours (SA, QES) \\
\hline 95 & X195 & 5 & $\begin{array}{l}\text { Labour Cost Index: (Salary and Wages rates): All } \\
\text { sectors combined }\end{array}$ \\
\hline 96 & X196 & 5 & Permanent and long-term migration: arrivals (SA) \\
\hline 97 & $\mathrm{X} 197$ & 5 & Permanent and long-term migration: departures (SA) \\
\hline 98 & X198 & 5 & Debt to gross assets (RBNZ estimate) \\
\hline 99 & X199 & 5 & Debt to disposable income (RBNZ estimate) \\
\hline 100 & $\mathrm{X} 200$ & 5 & $\begin{array}{l}\text { Housing value as percent of household disposable in- } \\
\text { come }\end{array}$ \\
\hline 101 & X201 & 5 & $\begin{array}{l}\text { Household net wealth as percent of household dispos- } \\
\text { able income }\end{array}$ \\
\hline 102 & $\mathrm{X} 202$ & 5 & Currency (SA) \\
\hline 103 & $\mathrm{X} 203$ & 5 & Notes and coins held by the public (SA) \\
\hline 104 & X204 & 5 & M1 (SA) \\
\hline 105 & $\mathrm{X} 205$ & 5 & $\mathrm{M} 2(\mathrm{SA})$ \\
\hline 106 & $\mathrm{X} 206$ & 5 & M3 (SA) \\
\hline 107 & $\mathrm{X} 207$ & 5 & Private Sector Credit (SA) \\
\hline 108 & $\mathrm{X} 208$ & 5 & Private Sector Credit Resident (SA) \\
\hline 109 & X209 & 5 & $\begin{array}{l}\text { Monthly housing price index (REINZ, NSA, } 3 \text { month } \\
\text { average) }\end{array}$ \\
\hline 110 & $\mathrm{X} 210$ & 5 & Quarterly House price Index (Quotable value, SA) \\
\hline 111 & $\mathrm{X} 211$ & 5 & House sales, Total NZ (Quotable value, SA) \\
\hline 112 & $\mathrm{X} 212$ & 5 & $\begin{array}{l}\text { House price index: Total NZ (for houses, flats, home } \\
\text { and income) (Quotable value, NSA) }\end{array}$ \\
\hline 113 & X213 & 1 & $\begin{array}{l}\text { RBNZ survey of expectations: Business: Expected } \\
\text { HLFS Unemployment Rate: } 1 \text { year ahead }\end{array}$ \\
\hline 114 & X214 & 1 & $\begin{array}{l}\text { RBNZ survey of expectations: Business: Expected } \\
\text { HLFS Unemployment Rate: } 2 \text { years ahead }\end{array}$ \\
\hline 115 & X215 & 1 & $\begin{array}{l}\text { QSBO survey: Finding skilled labour: Net (SA, } \\
\text { NZIER) }\end{array}$ \\
\hline 116 & X216 & 1 & $\begin{array}{l}\text { QSBO survey: Economy wide: New Investment: } \\
\text { Buildings: Net (SA, NZIER) }\end{array}$ \\
\hline 117 & $\mathrm{X} 217$ & 1 & $\begin{array}{l}\text { QSBO survey: Economy wide: New Investment: } \\
\text { Plant and Machinery: Net (SA, NZIER) }\end{array}$ \\
\hline 118 & X218 & 1 & $\begin{array}{l}\text { QSBO survey: Manufacturing: General business sit- } \\
\text { uation: Net (SA, NZIER) }\end{array}$ \\
\hline 119 & X219 & 1 & $\begin{array}{l}\text { RBNZ survey of expectations: Business: Expected } \\
\text { Quarterly (SA) GDP: Previous quarter }\end{array}$ \\
\hline 120 & $\mathrm{X} 220$ & 1 & $\begin{array}{l}\text { RBNZ survey of expectations: Business: Expected } \\
\text { Quarterly (S.A.) GDP: Current quarter }\end{array}$ \\
\hline
\end{tabular}


Table 3: Data

\begin{tabular}{|c|c|c|c|}
\hline $\begin{array}{l}\text { Variable num- } \\
\text { ber }\end{array}$ & Mnenomics & Transformation & Description \\
\hline 121 & $\mathrm{X} 221$ & 1 & $\begin{array}{l}\text { RBNZ survey of expectations: Business: Expected } \\
\text { Annual \% change GDP: } 1 \text { year ahead }\end{array}$ \\
\hline 122 & $\mathrm{X} 222$ & 1 & $\begin{array}{l}\text { RBNZ survey of expectations: Business: Expected } \\
\text { Annual \% change GDP: } 2 \text { years ahead }\end{array}$ \\
\hline 123 & $\mathrm{X} 223$ & 1 & $\begin{array}{l}\text { QSBO survey: Economy wide: Number employed: } \\
\text { past } 3 \text { months: Net (SA, NZIER) }\end{array}$ \\
\hline 124 & $\mathrm{X} 224$ & 1 & $\begin{array}{l}\text { QSBO survey: Economy wide: Number employed: } \\
\text { next } 3 \text { months: Net (SA,NZIER) }\end{array}$ \\
\hline 125 & $\mathrm{X} 225$ & 1 & $\begin{array}{l}\text { QSBO survey: Economy wide: Profitability: past } 3 \\
\text { months: Net (SA,NZIER) }\end{array}$ \\
\hline 126 & $\mathrm{X} 226$ & 1 & $\begin{array}{l}\text { QSBO survey: Economy wide: Profitability: next } 3 \\
\text { months: Net (SA, NZIER) }\end{array}$ \\
\hline 127 & $\mathrm{X} 227$ & 1 & $\begin{array}{l}\text { QSBO survey: Economy wide: Domestic trading ac- } \\
\text { tivity: past } 3 \text { months (SA, NZIER) }\end{array}$ \\
\hline 128 & $\mathrm{X} 228$ & 1 & $\begin{array}{l}\text { QSBO survey: Economy wide: Domestic trading ac- } \\
\text { tivity: next } 3 \text { months (SA, NZIER) }\end{array}$ \\
\hline 129 & X229 & 1 & $\begin{array}{l}\text { QSBO survey: Manufacturing and Builders - Capac- } \\
\text { ity Utilization (SA, NZIER) }\end{array}$ \\
\hline 130 & $\mathrm{X} 230$ & 1 & $\begin{array}{l}\text { QSBO survey: Economy wide: General business sit- } \\
\text { uation (SA, NZIER) }\end{array}$ \\
\hline 131 & $\mathrm{X} 231$ & 1 & $\begin{array}{l}\text { QSBO surveys: Economy wide: Capacity Utilization } \\
\text { (NZIER) }\end{array}$ \\
\hline 132 & $\mathrm{X} 232$ & 1 & $\begin{array}{l}\text { QSBO survey: Economy wide: Exporters Capacity } \\
\text { Utilization (NZIER) }\end{array}$ \\
\hline 133 & $\mathrm{X} 233$ & 1 & $\begin{array}{l}\text { QSBO survey: Economy wide: Past } 3 \text { months: Num- } \\
\text { ber employed (NZIER) }\end{array}$ \\
\hline 134 & $\mathrm{X} 234$ & 1 & $\begin{array}{l}\text { QSBO survey: Economy wide: Next } 3 \text { months: Num- } \\
\text { ber employed (NZIER) }\end{array}$ \\
\hline 135 & $\mathrm{X} 235$ & 1 & $\begin{array}{l}\text { QSBO survey: Economy wide: Next } 3 \text { months: Do- } \\
\text { mestic Trading activity (SA, NZIER) }\end{array}$ \\
\hline 136 & $\mathrm{X} 236$ & 1 & $\begin{array}{l}\text { QSBO survey: Economy wide: Past } 3 \text { months: Do- } \\
\text { mestic Trading activity (SA, NZIER) }\end{array}$ \\
\hline 137 & $\mathrm{X} 237$ & 1 & $\begin{array}{l}\text { National Bank survey: Business Confidence: Next } 12 \\
\text { month: Total ( } 3 \text { month average) }\end{array}$ \\
\hline 138 & $\mathrm{X} 238$ & 1 & $\begin{array}{l}\text { National Bank survey: Activity Outlook: Next } 12 \\
\text { month: Total ( } 3 \text { month average) }\end{array}$ \\
\hline 139 & X239 & 1 & $\begin{array}{l}\text { National Bank survey: Interest rate expectations: } \\
\text { Next } 12 \text { months: Services ( } 3 \text { month average) }\end{array}$ \\
\hline 140 & $\mathrm{X} 240$ & 1 & $\begin{array}{l}\text { National Bank survey: Capacity Utilisation: Total ( } 3 \\
\text { month average) }\end{array}$ \\
\hline 141 & $\mathrm{X} 241$ & 1 & $\begin{array}{l}\text { National Bank survey: Capacity Utilisation: Manu- } \\
\text { facturing ( } 3 \text { month average) }\end{array}$ \\
\hline 142 & $\mathrm{X} 242$ & 1 & $\begin{array}{l}\text { National Bank survey: Employment intentions: Next } \\
12 \text { months: Total ( } 3 \text { month average) }\end{array}$ \\
\hline 143 & $\mathrm{X} 243$ & 1 & $\begin{array}{l}\text { National Bank survey: Pricing intentions: Next } 3 \\
\text { months: Total ( } 3 \text { month average) }\end{array}$ \\
\hline 144 & $\mathrm{X} 244$ & 1 & $\begin{array}{l}\text { Westpac-McDermot-Miller Consumer Confidence In- } \\
\text { dex }\end{array}$ \\
\hline 145 & $\mathrm{X} 245$ & 1 & $\begin{array}{l}\text { Marketscope/UMR survey of expectations: Current } \\
\text { inflation }\end{array}$ \\
\hline 146 & $\mathrm{X} 246$ & 1 & $\begin{array}{l}\text { Marketscope/UMR survey of expectations: Net \% } \\
\text { Expect Higher Inflation: } 12 \text { Months }\end{array}$ \\
\hline 147 & $\mathrm{X} 247$ & 1 & $\begin{array}{l}\text { Marketscope/UMR survey of expectations: Expected } \\
\text { Inflation: } 12 \text { Months: Median }\end{array}$ \\
\hline 148 & $\mathrm{X} 248$ & 5 & Consents: Dwellings: Total new / altered value (SA) \\
\hline 149 & $\mathrm{X} 249$ & 5 & $\begin{array}{l}\text { Consents: Dwellings: Houses and flats: New: Num- } \\
\text { ber (SA) }\end{array}$ \\
\hline
\end{tabular}


Table 3: Data

\begin{tabular}{|c|c|c|c|c|}
\hline $\begin{array}{l}\text { Variable } \\
\text { ber }\end{array}$ & num- & Mnenomics & Transformation & Description \\
\hline 150 & & $\mathrm{X} 250$ & 5 & $\begin{array}{l}\text { Consents: Dwellings: Total new / altered number } \\
\text { (SA) }\end{array}$ \\
\hline 151 & & $\mathrm{X} 251$ & 5 & $\begin{array}{l}\text { Consents: Dwellings: Non-apartment dwelling units: } \\
\text { Number (SA) }\end{array}$ \\
\hline 152 & & $\mathrm{X} 252$ & 5 & Total Dwellings: New: Value (quarterly total) \\
\hline 153 & & $\mathrm{X} 253$ & 5 & Total Dwellings: New: Floor area (quarterly total) \\
\hline 154 & & $\mathrm{X} 254$ & 5 & New residential buildings: Units: Total \\
\hline 155 & & $\mathrm{X} 255$ & 5 & New residential buildings: Value: Total \\
\hline 156 & & $\mathrm{X} 256$ & 5 & Building work put in place: Dwellings: Total (SA) \\
\hline 157 & & $\mathrm{X} 257$ & 5 & Real Building work put in place: Residential (SA) \\
\hline 158 & & $\mathrm{X} 258$ & 5 & Real Building work put in place: Non-residential (SA) \\
\hline 159 & & $\mathrm{X} 259$ & 5 & Real Building work put in place: All buildings (SA) \\
\hline 160 & & $\mathrm{X} 260$ & 4 & $\begin{array}{l}\text { Australia: Nominal Effective Exchange Rate } \\
(2005=100)\end{array}$ \\
\hline 161 & & $\mathrm{X} 261$ & 4 & $\begin{array}{l}\text { Euro Area: Nominal Effective Exchange Rate (Avg, } \\
\text { NSA, } 2005=100)\end{array}$ \\
\hline 162 & & $\mathrm{X} 262$ & 4 & $\begin{array}{l}\text { Euro Area: Real Effective Exchange Rate based on } \\
\text { relative CPI }(2005=100)\end{array}$ \\
\hline 163 & & $\mathrm{X} 263$ & 4 & $\begin{array}{l}\text { Japan: Nominal Effective Exchange Rate (Avg, } \\
\text { NSA,2005 }=100 \text { ) }\end{array}$ \\
\hline 164 & & $\mathrm{X} 264$ & 4 & $\begin{array}{l}\text { Japan: Real Effective Exchange Rate: Consumer } \\
\text { Price basis }(2005=100)\end{array}$ \\
\hline 165 & & $\mathrm{X} 265$ & 4 & $\begin{array}{l}\text { United Kingdom: Nominal Effective Exchange Rate } \\
(\text { Avg, NSA,2005=100) }\end{array}$ \\
\hline 166 & & $\mathrm{X} 266$ & 4 & $\begin{array}{l}\text { U.K.: Real Effective Exch Rate: Consumer Price ba- } \\
\text { sis }(2005=100)\end{array}$ \\
\hline 167 & & $\mathrm{X} 267$ & 4 & $\begin{array}{l}\text { United States: Nominal Effective Exchange Rate } \\
(\text { Avg, NSA, 2005 }=100)\end{array}$ \\
\hline 168 & & $\mathrm{X} 268$ & 4 & $\begin{array}{l}\text { U.S.: Real Effective Exch Rate: Consumer Price basis } \\
(2005=100)\end{array}$ \\
\hline 169 & & $\mathrm{X} 269$ & 4 & $\begin{array}{l}\text { China, PR: Nominal Effective Exchange Rate } \\
(2005=100)\end{array}$ \\
\hline 170 & & $\mathrm{X} 270$ & 4 & $\begin{array}{l}\text { China, PR: Real Effective Exch Rate: Consumer } \\
\text { Price basis }(2005=100)\end{array}$ \\
\hline 171 & & $\mathrm{X} 271$ & 4 & $\begin{array}{l}\text { Canada: Nominal Effective Exchange Rate (Avg, } \\
\text { NSA,2005 }=100 \text { ) }\end{array}$ \\
\hline 172 & & $\mathrm{X} 272$ & 4 & $\begin{array}{l}\text { Canada: Real Effective Exchange Rate: Consumer } \\
\text { Price Basis }(2005=100)\end{array}$ \\
\hline 173 & & $\mathrm{X} 273$ & 1 & $\begin{array}{l}\text { Australia: A } \$ \text { Exchange Rate: USA (EOP, US } / A \text { ), } \\
\text { RBA }\end{array}$ \\
\hline 174 & & $\mathrm{X} 274$ & 1 & Australia: Official Cash Rate (EOP, \%) \\
\hline 175 & & $\mathrm{X} 275$ & 1 & $\begin{array}{l}\text { Canada: Overnight Money Market Financing Rate } \\
\text { [Target] (EOP, \%) }\end{array}$ \\
\hline 176 & & $\mathrm{X} 276$ & 1 & $\begin{array}{l}\text { U.S.: Federal Open Market Committee: Fed Funds } \\
\text { Target Rate (EOP, \%) }\end{array}$ \\
\hline 177 & & $\mathrm{X} 277$ & 1 & Australia: 3-Month Bank Accepted Bills (AVG, \%) \\
\hline 178 & & $\mathrm{X} 278$ & 1 & $\begin{array}{l}\text { U.K.: 3-Month London Interbank Offered Rate: } \\
\text { Based on British Pound (AVG, \%) }\end{array}$ \\
\hline 179 & & $\mathrm{X} 279$ & 1 & $\begin{array}{l}\text { U.S.: 3-Month London Interbank Offered Rate: } \\
\text { Based on US } \$(A V G, \%)\end{array}$ \\
\hline 180 & & $\mathrm{X} 280$ & 1 & Australia: 3-Month Bank Accepted Bills (EOP, \%) \\
\hline 181 & & $\mathrm{X} 281$ & 1 & $\begin{array}{l}\text { Japan: Call Rate: Uncollateralized 3-Month (EOP, } \\
\%)\end{array}$ \\
\hline 182 & & $\mathrm{X} 282$ & 1 & Australia: 5-Year Treasury Bond Yield (EOP, \%) \\
\hline 183 & & $\mathrm{X} 283$ & 1 & Australia: 10-Year Treasury Bond Yield (AVG, \%) \\
\hline 184 & & $\mathrm{X} 284$ & 1 & $\begin{array}{l}\text { Canada: 1-Year Treasury Bill Yield [Last Wednesday] } \\
\text { (EOP, \%) }\end{array}$ \\
\hline
\end{tabular}


Table 3: Data

\begin{tabular}{|c|c|c|c|}
\hline $\begin{array}{l}\text { Variable num- } \\
\text { ber }\end{array}$ & Mnenomics & Transformation & Description \\
\hline 185 & $\mathrm{X} 285$ & 1 & $\begin{array}{l}\text { Canada: 5-Year Benchmark Bond Yield [Last } \\
\text { Wednesday] (EOP, \%) }\end{array}$ \\
\hline 186 & $\mathrm{X} 286$ & 1 & Canada: 10-Year Benchmark Bond Yield (AVG, \%) \\
\hline 187 & $\mathrm{X} 287$ & 1 & $\begin{array}{l}\text { EA 11-17: 5-Year Benchmark Government Bond } \\
\text { Yield (AVG, \%) }\end{array}$ \\
\hline 188 & X288 & 1 & $\begin{array}{l}\text { EA 11-17: 10-Year Benchmark Government Bond } \\
\text { Yield (AVG, \%) }\end{array}$ \\
\hline 189 & X289 & 1 & $\begin{array}{l}\text { Japan: 1-Year Benchmark Government Bond Yield } \\
\text { (AVG, \% p.a.) }\end{array}$ \\
\hline 190 & X290 & 1 & $\begin{array}{l}\text { Japan: 5-Year Benchmark Government Bond Yield } \\
\text { (AVG, \% p.a.) }\end{array}$ \\
\hline 191 & X291 & 1 & $\begin{array}{l}\text { Japan: 10-Year Benchmark Government Bond Yield } \\
\text { (AVG, \% p.a.) }\end{array}$ \\
\hline 192 & X292 & 1 & $\begin{array}{l}\text { New Zealand: 10-Year Government Bond Yield } \\
\text { (EOP, \%) }\end{array}$ \\
\hline 193 & X293 & 1 & $\begin{array}{l}\text { U.K.: 1-Year London Interbank Offered Rate: Based } \\
\text { on British Pound }(\%)\end{array}$ \\
\hline 194 & X294 & 1 & $\begin{array}{l}\text { U.K.: Government Bonds, 5-Year Nominal Par Yield } \\
\text { (AVG, \%) }\end{array}$ \\
\hline 195 & X295 & 1 & $\begin{array}{l}\text { U.K.: Government Bonds, 10-Year Nominal Par } \\
\text { Yield (AVG, \%) }\end{array}$ \\
\hline 196 & X296 & 1 & $\begin{array}{l}\text { U.S.: 1-Year Treasury Bill Yield at Constant Matu- } \\
\text { rity }(\%)\end{array}$ \\
\hline 197 & X297 & 1 & $\begin{array}{l}\text { U.S.: 5-Year Treasury Note Yield at Constant Matu- } \\
\text { rity (\%) }\end{array}$ \\
\hline 198 & X298 & 1 & $\begin{array}{l}\text { U.S.: } 10 \text {-Year Treasury Bond Yield at Constant Ma- } \\
\text { turity (AVG, \%) }\end{array}$ \\
\hline 199 & X299 & 5 & $\begin{array}{l}\text { Australia: Gross Domestic Product (SA, } \\
\text { Mil.Chn.Q3:09-Q2:10.A } \$ \text { ) }\end{array}$ \\
\hline 200 & X300 & 5 & $\begin{array}{l}\text { EA 17: Gross Domestic Product (SA/WDA, } \\
\text { Mil.Chn.2005.Euros) }\end{array}$ \\
\hline 201 & X301 & 5 & $\begin{array}{l}\text { Canada: Gross Domestic Product (SAAR, } \\
\text { Mil.Chn.2002.C } \$ \text { ) }\end{array}$ \\
\hline 202 & X302 & 5 & $\begin{array}{lrrr}\text { Japan: } & \text { Gross } & \text { Domestic } & \text { Product } \\
\text { Bil.Chn.2005.Yen) } & & \end{array}$ \\
\hline 203 & X303 & 5 & $\begin{array}{l}\text { U.K.: Gross Domestic Product (SA, } \\
\text { Mil.Chained.2008.Pounds) }\end{array}$ \\
\hline 204 & X304 & 5 & $\begin{array}{llll}\text { U.S.: Gross Domestic Product } & \text { (SAAR, } \\
\text { Bil.Chn.2005\$) } & & \end{array}$ \\
\hline 205 & X305 & 5 & China: Gross Domestic Product (SA, Bil.2000.Yuan) \\
\hline 206 & X306 & 5 & Canada: Consumer Price Index $(\mathrm{SA}, 2002=100)$ \\
\hline 207 & $\mathrm{X} 307$ & 5 & $\begin{array}{l}\text { EA 11-17: Monetary Union: Index of Consumer } \\
\text { Prices(SA/H, 2005=100) }\end{array}$ \\
\hline 208 & X308 & 5 & Japan: Consumer Price Index (SA/H, 2010=100) \\
\hline 209 & X309 & 5 & $\begin{array}{l}\text { U.K.: Harmonized Index of Consumer Prices [HICP] } \\
(\mathrm{SA}, 2005=100)\end{array}$ \\
\hline 210 & X310 & 5 & U.S.: Consumer Price Index (SA, 1982-84=100) \\
\hline 211 & X311 & 5 & China: Consumer Price Index (SA, 2005=100) \\
\hline 212 & X312 & 5 & $\begin{array}{l}\text { Canada: Industrial Price Index: All Commodities } \\
\text { (SA, 2002=100) }\end{array}$ \\
\hline 213 & X313 & 5 & $\begin{array}{l}\text { EA 17: PPI: Industry excluding Construction (SA, } \\
2005=100 \text { ) }\end{array}$ \\
\hline 214 & X314 & 5 & $\begin{array}{l}\text { Japan: Output Price: Manufacturing (SA, } \\
2005=100)\end{array}$ \\
\hline 215 & $\mathrm{X} 315$ & 5 & $\begin{array}{l}\text { U.K.: PPI: Net Output Prices: Manufactured Prod- } \\
\text { ucts (SA, } 2005=100)\end{array}$ \\
\hline 216 & X316 & 5 & U.S.: PPI: Finished Goods (SA, $1982=100)$ \\
\hline
\end{tabular}


Table 3: Data

\begin{tabular}{|c|c|c|c|}
\hline $\begin{array}{l}\text { Variable num- } \\
\text { ber }\end{array}$ & Mnenomics & Transformation & Description \\
\hline 217 & X317 & 5 & Australia: Terms of Trade $(\mathrm{SA}, 2005=100)$ \\
\hline 218 & X318 & 5 & Canada: Terms of Trade (SA, 2005=100) \\
\hline 219 & X319 & 5 & EA 17: Terms of Trade $(\mathrm{SA}, 2005=100)$ \\
\hline 220 & X320 & 5 & Japan: Terms of Trade $(\mathrm{SA}, 2005=100)$ \\
\hline 221 & X321 & 5 & U.K.: Terms of Trade $(\mathrm{SA}, 2005=100)$ \\
\hline 222 & $\mathrm{X} 322$ & 5 & U.S.: Terms of Trade $(\mathrm{SA}, 2005=100)$ \\
\hline 223 & $\mathrm{X} 323$ & 5 & $\begin{array}{l}\text { Australia: } \\
\text { Q2.90=100) }\end{array} \quad$ Import Price $\quad$ Index $\quad$ (SA, Q3.89- \\
\hline 224 & X324 & 5 & $\begin{array}{l}\text { Canada: Import Price Index: Laspeyres Fixed } \\
\text { Weighted }(\mathrm{SA}, 2002=100)\end{array}$ \\
\hline 225 & X325 & 5 & EA 17: Import Prices: Total $(S A, 2000=100)$ \\
\hline 226 & X326 & 5 & $\begin{array}{l}\text { Japan: Import Price Index: All Commodities (SA, } \\
2005=100)\end{array}$ \\
\hline 227 & X327 & 5 & $\begin{array}{l}\text { U.K.: Import Price Index: Total Goods (SA, } \\
2008=100)\end{array}$ \\
\hline 228 & X328 & 5 & $\begin{array}{l}\text { U.S.: Import Price Index: All Imports (SA, } \\
2000=100)\end{array}$ \\
\hline 229 & X329 & 5 & $\begin{array}{lllll}\text { Australia: } & \text { Export } & \text { Price } & \text { Index } & \text { (SA, Q3.89- } \\
\text { Q2.90=100) } & & & & \end{array}$ \\
\hline 230 & X330 & 5 & $\begin{array}{l}\text { Canada: Export Price Index: Laspeyres Fixed } \\
\text { Weighted }(\mathrm{SA}, 2002=100)\end{array}$ \\
\hline 231 & X331 & 5 & $\begin{array}{l}\text { Japan: Export Price Index: All Commodities (SA, } \\
2005=100)\end{array}$ \\
\hline 232 & X332 & 5 & $\begin{array}{l}\text { New Zealand: Export Price Index: Goods (SA, Q2- } \\
02=1000)\end{array}$ \\
\hline 233 & X333 & 5 & $\begin{array}{l}\text { U.K.: Export Price Index: Total Goods (SA, } \\
2008=100)\end{array}$ \\
\hline 234 & X334 & 5 & $\begin{array}{l}\text { U.S.: Export Price Index: All Exports (SA, } \\
2000=100)\end{array}$ \\
\hline 235 & X335 & 5 & $\begin{array}{l}\text { Australia: Industrial Production excl Construction } \\
\text { (SA, Q3.09-Q2.10=100) }\end{array}$ \\
\hline 236 & X336 & 5 & $\begin{array}{l}\text { Canada: Industrial Production Manufacturing, Min- } \\
\text { ing \& Utilities }(\text { SA, 2002=100) }\end{array}$ \\
\hline 237 & X337 & 5 & $\begin{array}{l}\text { EA 17: IP: Industry excluding Construction } \\
(\text { SA } / \text { WDA, } 2005=100)\end{array}$ \\
\hline 238 & X338 & 5 & $\begin{array}{l}\text { New Zealand: Industrial Production excl Construc- } \\
\text { tion (SA, Q3.95-Q2.96=100) }\end{array}$ \\
\hline 239 & X339 & 5 & $\begin{array}{l}\text { U.K.: Industrial Production excluding Construction } \\
(\mathrm{SA}, 2008=100)\end{array}$ \\
\hline 240 & X340 & 5 & $\begin{array}{l}\text { U.S.: Industrial Production excluding Construction } \\
(\mathrm{SA}, 2007=100)\end{array}$ \\
\hline 241 & X341 & 1 & Australia: Unemployment Rate (SA, \%) \\
\hline 242 & X342 & 1 & $\begin{array}{l}\text { Canada: Unemployment Rate: } 15 \text { Years and Over } \\
(\mathrm{SA}, \%)\end{array}$ \\
\hline 243 & X343 & 1 & EA 17: Unemployment Rate (SA, \%) \\
\hline 244 & X344 & 1 & Japan: Unemployment Rate (SA, \%) \\
\hline 245 & $\mathrm{X} 345$ & 1 & $\begin{array}{l}\text { U.K.: Unemployment Rate: Aged } 16 \text { and Over [3-Mo } \\
\text { Moving Avg](SA, \%) }\end{array}$ \\
\hline 246 & X346 & 1 & U.S.: Civilian Unemployment Rate (SA, \%) \\
\hline 247 & X347 & 1 & $\begin{array}{l}\text { Australia: NAB Business Survey: Capacity Utiliza- } \\
\text { tion (NSA, \%) }\end{array}$ \\
\hline 248 & X348 & 1 & $\begin{array}{l}\text { Japan: Operating Rate: Manufacturing (NSA, } \\
2005=100)\end{array}$ \\
\hline 249 & X349 & 1 & $\begin{array}{l}\text { Australia: NAB Business Survey: Capacity Utiliza- } \\
\text { tion (SA, \%) }\end{array}$ \\
\hline 250 & X350 & 1 & $\begin{array}{l}\text { Canada: Capacity Utilization: Total Industrial (SA, } \\
\% \text { ) }\end{array}$ \\
\hline
\end{tabular}


Table 3: Data

\begin{tabular}{|c|c|c|c|}
\hline $\begin{array}{l}\text { Variable num- } \\
\text { ber }\end{array}$ & Mnenomics & Transformation & Description \\
\hline 251 & X351 & 1 & EA 17: Capacity Utilization: Manufacturing (SA, \%) \\
\hline 252 & $\mathrm{X} 352$ & 1 & $\begin{array}{l}\text { Japan: Operating Rate: Manufacturing (SA, } \\
2005=100)\end{array}$ \\
\hline 253 & $\mathrm{X} 353$ & 1 & U.S.: Capacity Utilization: Industry (SA, \%) \\
\hline 254 & X354 & 5 & Australia: Imports of Goods, cif (SA, Mil.A $\$$ ) \\
\hline 255 & X355 & 5 & Canada: Imports of Goods, BOP Basis (SA, Mil C\$) \\
\hline 256 & X356 & 5 & EA 17: Imports of Goods (SA/WDA, Thous.Euros) \\
\hline 257 & X357 & 5 & Japan: Imports of Goods (SA, Bil.Yen) \\
\hline 258 & X358 & 5 & New Zealand: Imports of Goods, cif (SA, Mil.NZ\$) \\
\hline 259 & X359 & 5 & U.K.: Imports of Goods (SA, Mil.Pounds) \\
\hline 260 & $\mathrm{X} 360$ & 5 & U.S.: Imports of Goods, Customs Value (SA, Mil.\$) \\
\hline 261 & X361 & 5 & Australia: Exports of Goods, fob (SA, Mil.A\$) \\
\hline 262 & X362 & 5 & Canada: Exports of Goods, BOP Basis (SA, Mil.C\$) \\
\hline 263 & X363 & 5 & EA 17: Exports of Goods (SA/WDA, Thous.Euros) \\
\hline 264 & X364 & 5 & Japan: Exports of Goods (SA, Bil.Yen) \\
\hline 265 & X365 & 5 & New Zealand: Exports of Goods, fob (SA, Mil.NZ\$) \\
\hline 266 & X366 & 5 & U.K.: Exports of Goods (SA, Mil.Pounds) \\
\hline 267 & X367 & 5 & U.S.: Exports of Goods, f.a.s. (SA, Mil.\$) \\
\hline 268 & X368 & 5 & China: Merchandise Imports, cif (SA, Bil.Yuan) \\
\hline 269 & X369 & 5 & China: Merchandise Exports, fob (SA, Bil.Yuan) \\
\hline 270 & X370 & 5 & $\begin{array}{l}\text { World: Commodity Price Index: All Commodities } \\
(2005=100)\end{array}$ \\
\hline 271 & X371 & 5 & $\begin{array}{l}\text { World: Non-fuel Primary Commodities Index } \\
(2005=100)\end{array}$ \\
\hline 272 & X372 & 5 & $\begin{array}{l}\text { World: Commodity Price Index: Agricultural Raw } \\
\text { Materials }(2005=100)\end{array}$ \\
\hline 273 & X373 & 5 & $\begin{array}{l}\text { World: Commodity Price Index: Food \& Beverage } \\
(2005=100)\end{array}$ \\
\hline 274 & $\mathrm{X} 374$ & 5 & $\begin{array}{l}\text { Value of Total Merchandise Exports (excludes re- } \\
\text { exports) (SA) }\end{array}$ \\
\hline 275 & X375 & 5 & OTI Value of Total Merchandise Imports (SA) \\
\hline 276 & Z101 & 5 & Import Price Index Capital Goods: Total \\
\hline 277 & Z102 & 5 & $\begin{array}{l}\text { Import price index - Petroleum and Petroleum Prod- } \\
\text { ucts }\end{array}$ \\
\hline 278 & $\mathrm{Z} 103$ & 5 & $\begin{array}{l}\text { Import price index - Total Non-Commodity Manufac- } \\
\text { tured Goods }\end{array}$ \\
\hline 279 & Z104 & 5 & $\begin{array}{l}\text { Import Price Index - Total Non-Oil Commodity } \\
\text { Goods }\end{array}$ \\
\hline 280 & Z105 & 5 & Import Price Index - Total Merchandise Imports \\
\hline 281 & $\mathrm{Z} 106$ & 5 & Export price index: Dairy Products (Agricultural) \\
\hline 282 & $\mathrm{Z} 107$ & 5 & Export price index: Meat (Food and Beverages) \\
\hline 283 & $\mathrm{Z} 108$ & 5 & Export price index of Total Manufactures \\
\hline 284 & Z109 & 5 & Export Price Index: All Merchandise \\
\hline 285 & $\mathrm{Z} 110$ & 5 & ANZ Commodity Price Index - NZ\$ \\
\hline 286 & Z111 & 5 & $\begin{array}{l}\text { ANZ Commodity Price Index - NZ\$ - Meat, skins and } \\
\text { wool }\end{array}$ \\
\hline 287 & $\mathrm{Z} 112$ & 5 & ANZ Commodity Price Index - NZ\$ - Dairy products \\
\hline 288 & Z113 & 5 & $\begin{array}{l}\text { ANZ Commodity Price Index - NZ } \$ \text { - Horticultural } \\
\text { products }\end{array}$ \\
\hline 289 & Z114 & 5 & New Zealand: Terms of Trade $(\mathrm{SA}, 2005=100)$ \\
\hline 290 & $\mathrm{Z} 115$ & 1 & $\begin{array}{l}\text { RBNZ survey of expectations: Business: Expected } \\
\text { Annual CPI: } 1 \text { year from now }\end{array}$ \\
\hline 291 & Z116 & 1 & $\begin{array}{l}\text { RBNZ survey of expectations: Business: Expected } \\
\text { Annual CPI: } 2 \text { years from now }\end{array}$ \\
\hline 292 & $\mathrm{Z} 117$ & 1 & $\begin{array}{l}\text { RBNZ survey of expectations: Business: Expected } \\
\text { 90-day Bank Bill - End current quarter }\end{array}$ \\
\hline
\end{tabular}


Table 3: Data

\begin{tabular}{|c|c|c|c|}
\hline $\begin{array}{l}\text { Variable num- } \\
\text { ber }\end{array}$ & Mnenomics & Transformation & Description \\
\hline 293 & Z118 & 1 & $\begin{array}{l}\text { RBNZ survey of expectations: Business: Expected } \\
\text { 90-day Bank Bill - } 3 \text { quarters from now }\end{array}$ \\
\hline 294 & Z119 & 1 & $\begin{array}{l}\text { RBNZ survey of expectations: Business: CPI - 1Q } \\
\text { expectation (Professional forecaster) }\end{array}$ \\
\hline 295 & Z120 & 1 & $\begin{array}{l}\text { RBNZ survey of expectations: Business: CPI }-2 \mathrm{Q} \\
\text { expectation (Professional forecaster) }\end{array}$ \\
\hline 296 & Z121 & 1 & $\begin{array}{l}\text { RBNZ survey of expectations: Business: CPI }-1 Y \\
\text { expectation (Professional forecaster) }\end{array}$ \\
\hline 297 & Z122 & 1 & $\begin{array}{l}\text { RBNZ survey of expectations: Business: CPI }-2 \mathrm{Y} \\
\text { expectation (Professional forecaster) }\end{array}$ \\
\hline 298 & Z123 & 1 & New Zealand: 5-Year Government Bond Yield (\%) \\
\hline 299 & Z124 & 1 & $\begin{array}{l}\text { New Zealand: 10-Year Government Bond Yield } \\
\text { (AVG, \%) }\end{array}$ \\
\hline 300 & Z125 & 5 & $\begin{array}{l}\text { New Zealand: Consumer Price Index (SA, Q2- } \\
06=1000 \text { ) }\end{array}$ \\
\hline 301 & Z126 & 5 & $\begin{array}{l}\text { New Zealand: Producer Price Index (SA, Q4- } \\
10=1000 \text { ) }\end{array}$ \\
\hline 302 & Z127 & 5 & $\begin{array}{l}\text { New Zealand: Import Price Index: Goods (SA, Q2- } \\
02=1000)\end{array}$ \\
\hline 303 & $\mathrm{Z} 128$ & 5 & $\begin{array}{l}\text { New Zealand: Capital Index: NZSX All Indexes } \\
\text { (Jun-30-86=1000) }\end{array}$ \\
\hline 304 & Z129 & 5 & $\begin{array}{l}\text { New Zealand: Gross Index: NZSX All Indexes (Jun- } \\
30-86=1000)\end{array}$ \\
\hline 305 & I1 & 1 & New Zealand: 90-Day Bank Bill Yield (AVG, \%) \\
\hline 305 & I2 & 1 & $\begin{array}{l}\text { New Zealand: Trade Weighted Exchange Rate (AVG, } \\
\% \text { ) }\end{array}$ \\
\hline
\end{tabular}


Table 4: Peak Impact and Levels of significance

\begin{tabular}{|c|c|c|c|}
\hline Variable & $\begin{array}{l}3 \text { Fac- } \\
\text { tors }\end{array}$ & 4 Factors & 5 Factors \\
\hline GDP sectors & & & \\
\hline Agriculture & $0.09 *(4)$ & $0.11 *(5)$ & $0.1(4)$ \\
\hline Forestry and Logging & $0.18 *(4)$ & $-0.13^{*}(4)$ & $0.1(10)$ \\
\hline $\begin{array}{l}\text { Fishing, Aquaculture and Agriculture, Forestry and Fishing Support Ser- } \\
\text { vices }\end{array}$ & $0.03(12)$ & $-0.08^{*}(3)$ & $-0.06^{*}(9)$ \\
\hline Mining & $0.11^{*}(6)$ & $-0.1^{*}(7)$ & $-0.1(5)$ \\
\hline Food, Beverage and Tobacco Product Manufacturing & $-0.3^{*}(5)$ & $-0.25^{*}(5)$ & $-0.23 *(5)$ \\
\hline Textile, Leather, Clothing and Footwear Manufacturing & $0.19 *(6)$ & $-0.23 *(6)$ & $-0.21 *(5)$ \\
\hline Wood and Paper Products Manufacturing & $0.26^{*}(4)$ & $-0.21^{*}(5)$ & $-0.18^{*}(4)$ \\
\hline Printing & $0.26^{*}(5)$ & $-0.27 *(5)$ & $-0.24^{*}(5)$ \\
\hline Petroleum, Chemical, Polymer and Rubber Product Manufacturing & $0.15^{*}(5)$ & $-0.09 *(5)$ & $-0.08^{*}(4)$ \\
\hline Non-Metallic Mineral Product Manufacturing & $0.31^{*}(6)$ & $-0.35 *(6)$ & $-0.32 *(6)$ \\
\hline Metal Product Manufacturing & $0.43^{*}(5)$ & $-0.33^{*}(5)$ & $-0.3^{*}(5)$ \\
\hline Transport Equipment, Machinery and Equipment Manufacturing & $0.41^{*}(6)$ & $-0.28^{*}(6)$ & $-0.25^{*}(6)$ \\
\hline Furniture and Other Manufacturing & $0.31^{*}(4)$ & $-0.3^{*}(4)$ & $-0.26 *(4)$ \\
\hline Electricity, Gas, Water and Waste Services & $0.03 *(3)$ & $0.04^{*}(9)$ & $0.04 *(8)$ \\
\hline Construction & $0.35 *(5)$ & $-0.45 *(5)$ & $-0.4^{*}(5)$ \\
\hline Wholesale Trade & $0.12 *(6)$ & $-0.1^{*}(6)$ & $-0.1 *(5)$ \\
\hline Retail Trade & $0.16^{*}(5)$ & $-0.18^{*}(5)$ & $-0.16^{*}(4)$ \\
\hline Accommodation and Food Services & $0.12 *(5)$ & $-0.11^{*}(5)$ & $-0.09 *(5)$ \\
\hline Transport, Postal and Warehousing & $0.17 *(6)$ & $-0.17^{*}(6)$ & $-0.15^{*}(6)$ \\
\hline Information Media and Telecommunications & - $0.04(10)$ & $-0.07 *(8)$ & $-0.07 *(7)$ \\
\hline Financial and Insurance Services & $0.02 *(3)$ & $-0.08^{*}(3)$ & $-0.08 *(9)$ \\
\hline Rental, Hiring and Real Estate Services & $0.08 *(4)$ & $-0.12 *(4)$ & $-0.09 *(4)$ \\
\hline Owner-Occupied Property Operation (National Accounts Only) & $0.01 *(5)$ & $-0.02 *(5)$ & $-0.02 *(5)$ \\
\hline Professional, Scientific and Technical Services & $0.04 *(5)$ & $-0.08 *(4)$ & $-0.07 *(4)$ \\
\hline Administrative and Support Services & $0.13 *(4)$ & $-0.16^{*}(4)$ & $-0.14^{*}(4)$ \\
\hline Local Government Administration & $0.04(3)$ & $-0.09^{*}(10)$ & $-0.09 *(10)$ \\
\hline Central Government Administration, Defence and Public Safety & $0.01^{*}(2)$ & $-0.11 *(9)$ & $-0.09 *(8)$ \\
\hline Education and Training & $\overline{-} .01(13)$ & $-0.01 *(3)$ & $-0.01(2)$ \\
\hline Health Care and Social Assistance & $0.04 *(4)$ & $-0.03^{*}(11)$ & $-0.03^{*}(10)$ \\
\hline Arts and Recreation Services & $\overline{0.06 *(5)}$ & $-0.07 *(5)$ & $-0.08^{*}(5)$ \\
\hline Other Services & $0.07 *(4)$ & $-0.1^{*}(4)$ & $-0.09 *(4)$ \\
\hline Employment & & & \\
\hline Forestry and Mining & $-\overline{0.09 *(3)}$ & $-0.13^{*}(4)$ & $-0.1^{*}(3)$ \\
\hline Manufacturing & $0.11 *(6)$ & $-0.15^{*}(6)$ & $-0.13^{*}(6)$ \\
\hline
\end{tabular}

Note: The table reports the estimated median peak impact coefficients from bootstrapping the VAR. The values in paranthesis report the quarter when this impact occurs. The stars indicate that these values are statistically significant (i.e. zero is not included within one-standard deviation confidence intervals generated from 5000 replications.) 
Table 4: Peak Impact and Levels of significance

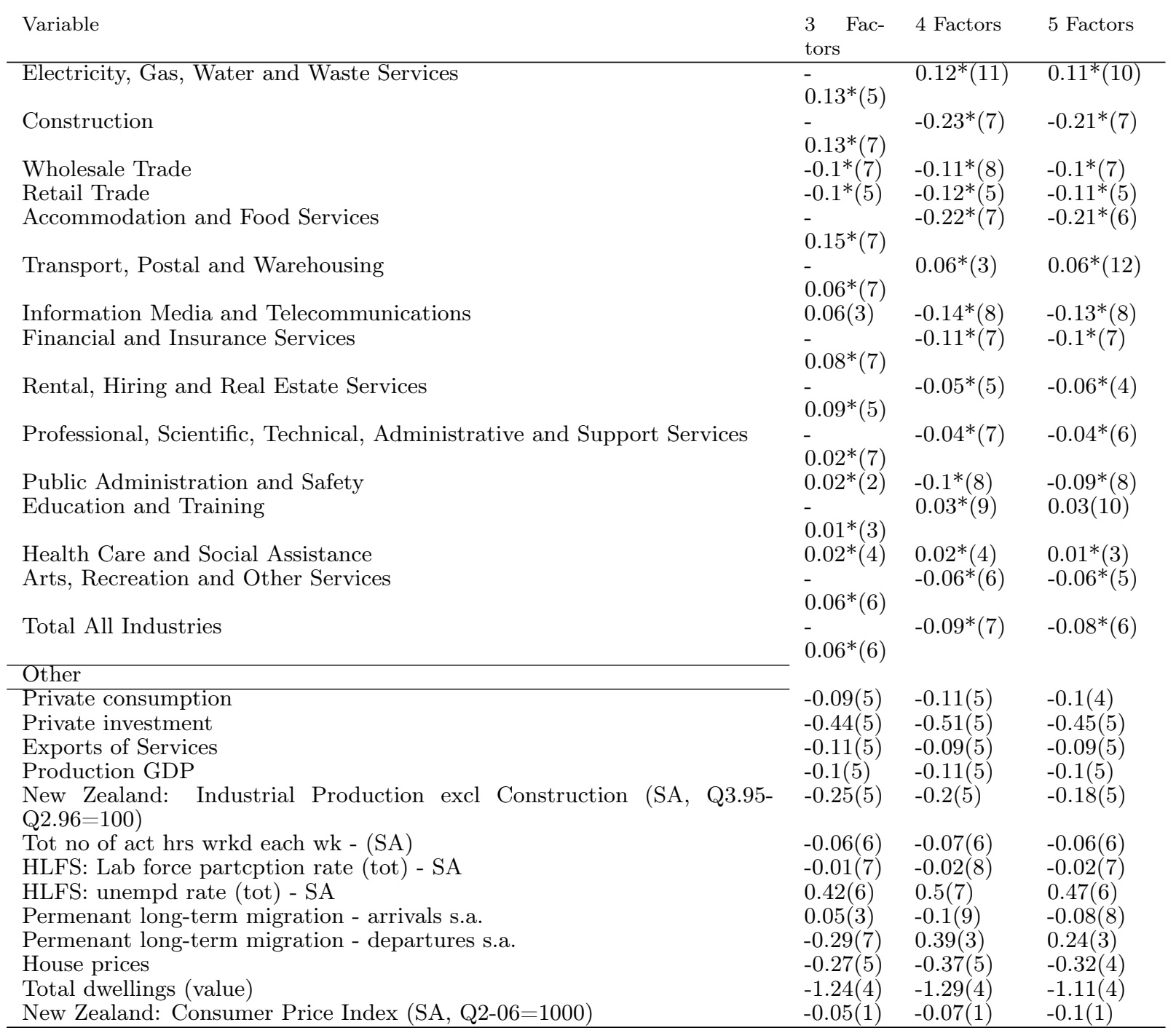

Note: The table reports the estimated median peak impact coefficients from bootstrapping the VAR. The values in paranthesis report the quarter when this impact occurs. The stars indicate that these values are statistically significant (i.e. zero is not included within one-standard deviation confidence intervals generated from 5000 replications.) 